\title{
NOTAS SOBRE AS ETAPAS DE DESENVOLVIMENTO DE TRÊS LAGOAS (MS): UM EXERCÍCIO ROSTOWIANO
}

\author{
Fabricio José Missio ${ }^{1}$ \\ Cláudia Maria Sonaglio² \\ Bruna Maria Oliveira Benites Ferreira ${ }^{3}$
}

Resumo: O objetivo do artigo é analisar o desenvolvimento econômico do município de Três Lagoas - MS. Mais especificamente, busca-se identificar e caracterizar as fases de desenvolvimento do referido município tendo como marco teórico as "Etapas do desenvolvimento econômico" proposto por Rostow (1978 [1961]). Evidentemente, trata-se de um exercício teórico/analítico. Justifica-se a análise pelo fato de o município ter atraído investimentos e se destacado (especialmente, mas não exclusivamente) em relação as demais municipalidades do estado (e do Brasil) como um modelo de polo industrial. Os principais resultados indicam que o processo de desenvolvimento de Três Lagoas tem elementos que permitem caracterizar que ele passou pelas três primeiras fases da referida teoria e que apresenta um conjunto de pré-requisitos capazes de impulsionar o "arranco" propriamente dito.

Palavras-chave: Desenvolvimento local. Etapas do desenvolvimento. Reestruturação produtiva. Arranco.

\section{DEVELOPMENT STAGES OF TRÊS LAGOAS (MS), BRAZIL.}

Abstract: The aim of this paper is to analyze the economic development of Três Lagoas - MS. More specifically, we seek to identify and characterize the development stages of this place having as theoretical framework the "Stages of development Economic Growth" proposed by Rostow (1961). This is a theoretical/analytical exercise. The main results indicate that this process of development passed through the first three stages of this theory, and that presents a set of prerequisites able to boost the take-off.

Keywords: Local development. Stages of development, productive restructuring, take-off.

\section{NOTAS SOBRE LOS ESTADIOS DEL DESARROLLO DE TRÊS LAGOAS (MS): UN EJERCICIO ROSTOWIANO}

Resumen: El objetivo del presente texto es analizar el desarrollo económico del ayuntamiento de Três Lagoas (MS). Específicamente, el objetivo es discutir los rasgos de los estadios del desarrollo de Tres Lagoas usando la teoría del "Las Etapas del crecimiento económico" de Rostow (1978 [1961]). El texto es un ejercicio puramente teórico. La motivación de este trabajo es el recién crecimiento de la inversión y la posición destacada de Três Lagoas con relación a los otros municipios de Brasil como

\footnotetext{
1 Universidade Federal de Minas Gerais, Departamento de Economia, Belo Horizonte, Brasil, Fjmissio@cedeplar.ufmg.br, https://orcid.org/0000-0003-4561-6039.

2 Universidade Estadual de Mato Grosso do Sul, Departamento de Economia, Ponta Porã, Brasil, claudia.sonagliol@gmail.br, https://orcid.org/0000-0003-2840-5440

${ }_{3}^{3}$ Universidade Estadual de Mato Grosso do Sul, Mestranda Desenvolvimento Regional e de Sistemas Produtivos, Ponta Porã, Brasil, bruna1maio@hotmail.com, https://orcid.org/0000-0002-1930-6187
} 
una zona industrial. Además, los resultados sugieren que el desarrollo de dicho município pasó por los tres estadios señalados por la teoría de Rostow y que existen las condiciones esenciales para generar el "despegue" en el municipio.

Palabras clave: Desarrollo local. Etapas del desarrollo. Reestructuración productiva. El despegue.

\section{Introdução}

A ideia de desenvolvimento, especialmente nas suas formulações iniciais, sempre esteve atrelada ao crescimento econômico. Este, por sua vez, seria o resultado do processo de industrialização, significando, deste modo, modernização (não só das condições econômicas, mas também das condições sociais, institucionais e ideológicas). Nesse contexto, uma série de autores (os "pioneiros" do desenvolvimento), incluindo Rostow, buscaram mostrar as condições necessárias para se alcançar tal modernização.

Segundo a teoria de Rostow, o desenvolvimento econômico é um processo dinâmico de sucessão de etapas subsequentes (ao longo de um mesmo caminho) até que as sociedades usufruam da "era do consumo em massa", que significa o ápice do desenvolvimento ${ }^{4}$. Com base nesse arcabouço teórico, o artigo tem por objetivo analisar o desenvolvimento econômico do município de Três Lagoas - MS ${ }^{5}$. Mais especificamente, busca-se identificar e caracterizar as fases de desenvolvimento do município a fim de identificar se ele já estabeleceu as pré-condições necessárias para o chamado "arranco" econômico. Ademais, apresentam-se evidências empíricas que permitam corroborar a análise empreendida.

Justifica-se a análise com base na concepção de que identificar os elementos que caracterizam as referidas etapas é um exercício teórico/analítico válido. Ademais, as recentes transformações da estrutura produtiva têm propiciado a Três Lagoas a possibilidade de manter um elevado ritmo de crescimento. Historicamente, a única atividade de destaque era a pecuária. Contudo, após o início do processo de industrialização, em 1997, ocorreram significativas mudanças na estrutura produtiva do município, de tal forma que a economia deixou de ser essencialmente dependente daquele setor. Por exemplo, considerando o ano de 2011 em relação ao de 2000,

\footnotetext{
${ }^{4}$ São cinco as etapas do desenvolvimento econômico: sociedade tradicional, precondições para o arranco, arranco propriamente dito, marcha para a maturidade e a era do consumo em massa.

${ }^{5} \mathrm{Em}$ termos populacionais, Três Lagoas é o terceiro maior município do estado de Mato Grosso do Sul (MS) com aproximadamente 111.652 mil habitantes. O município encontra-se localizado a 324KM da capital, Campo Grande, e tem uma área territorial de $10.206 \mathrm{~m}^{2}$, o que representa 2,58\% da área total do estado (IBGE, 2014).
} 
observa-se que a participação do valor adicionado do setor da agropecuária reduziuse de $11,2 \%$ para $3,5 \%$, ao mesmo tempo em que o PIB industrial cresceu $1.258 \%$ (IBGE, 2014).

Em termos metodológicos, cumpre ressaltar que a abordagem de Rostow é muito específica em alguns pontos, enquanto em outros ele é muito mais geral. Todavia, é fato que seu modelo relativamente detalhado é importante porque forneceu uma estrutura analítica que identifica fatores que foram aceitos como cruciais no processo de crescimento. Embora sua descrição do desenvolvimento não seja tão verificável ou absoluta quanto muitos gostariam, ele identifica parâmetros gerais que fornecem primeiras aproximações úteis.

Recentemente, desdobramentos desse modelo ${ }^{6}$ - que é a perpectiva assumida nesse artigo - passaram a explorar os estágios de crescimento econômico de Rostow em termos regionais ${ }^{7}$, com três perspectivas distintas: regional (com o foco em uma região e a exclusão de outras regiões), multirregional (com o aspecto de muitas regiões) e inter-regional ((com o foco principal nas relações do regiões) (ver Parr, 2001; Arora, 2009). Um dos argumentos de Parr (2011) é de que, como as economias subnacionais são altamente abertas, as perspectivas de variações espaciais no desenvolvimento podem ser esperadas em diferentes escalas, porque a produtividade pode ser transmitida via comércio direta, indiretamente e/ou por efeito de realimentação (voltaremos a este ponto). Nosso foco aqui é em uma perspectiva regional (municipio de Três Lagoas), sem referência direta à economia nacional ou outras regiões dentro de MS ou do Brasil.

O trabalho está estruturado em duas seções, além desta introdução e das considerações finais. Na seção 2, resgatam-se os principais elementos presentes na obra de Rostow, enquanto, na seção seguinte, busca-se traçar um raciocínio comparativo que visa analisar o estágio de desenvolvimento econômico de Três Lagoas com base nas etapas do desenvolvimento proposta pelo referido autor.

\footnotetext{
${ }^{6}$ Algumas das principais críticas ao trabalho de Rostow apontam para a falha desta teoria em explorar completamente a diferenciação e as disparidades que ocorrem dentro das nações; além da suposição de uniformidade entre as nações (Hoselitz, 1960; Cairncross, 1961; Kuznets, 1963 e ltagaki, 1963 entre outros). De certa forma, a perpectiva regional inaugurada por Parr (2001) é uma tentativa de contornar estes problemas.

7 Segundo Arora (2009), Rostow (1978) incorporou a perpectiva regional ao discutir a decolagem da Nova Inglaterra (EUA); de São Paulo (Brasil) e da Manchúria (China).
} 


\section{Etapas do Desenvolvimento Econômico}

Rostow salienta, no primeiro capítulo de sua obra "Etapas do desenvolvimento econômico", que:

Este livro apresenta uma generalização da marcha da História moderna feita por um historiador da economia. A forma de tal generalização é um conjunto das etapas de desenvolvimento. Aos poucos, cheguei à conclusão de que é viável e, para determinados fins limitados, útil decompor a história de cada economia nacional - e por vezes a de regiões inteiras - de acordo com este conjunto de etapas. Elas constituem, no fim de contas, tanto uma teoria sobre o desenvolvimento econômico quanto uma teoria mais geral, embora ainda consideravelmente parcial, sobre a totalidade da História moderna (ROSTOW, 1978, p. 13).

A passagem anterior traz a síntese do pensamento do autor, isto é, a propulsão e a sustentação do desenvolvimento econômico estão compreendidas em etapas (Figura 1).

Figura 1: Etapas do desenvolvimento segundo Rostow

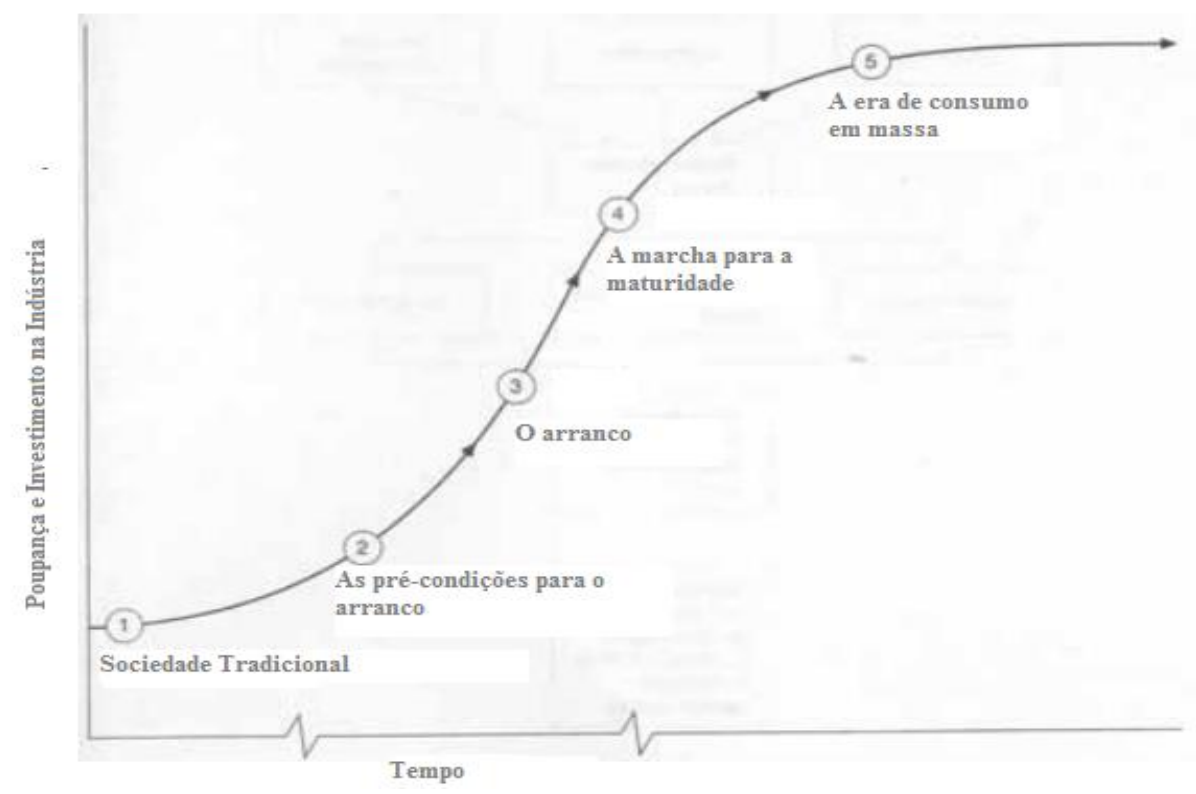

Fonte: Adaptado de Potter, Binns, Eliott \& Smiith (1999, p. 51)

Mais especificamente, as etapas e suas principais características podem ser sintetizadas como segue: 
1 - Sociedade Tradicional: A sociedade tradicional ocorre por um período de um século, aproximadamente. Essa etapa é caracterizada pelas economias agrícolas, com métodos de produção razoavelmente estáveis, em que há investimentos minimamente superiores à depreciação. Contudo, a economia não é necessariamente estática, nem exclui aumentos do volume de produção. A área cultivada pode ser dilatada e algumas inovações tecnológicas podem ser introduzidas. $O$ fato central, porém, é que nessas sociedades existe um teto no volume alcançável da produção per capita.

A produção é caracterizada por ser intensiva em trabalho e com baixa densidade de capital, e a alocação é determinada majoritariamente pelos tradicionais métodos de produção, refletidos em um nível de produtividade também limitado. $\mathrm{A}$ taxa de investimento produtivo pode chegar a $5 \%$ da renda nacional, mas é provavelmente menor que a taxa de crescimento da população. A economia é basicamente agrícola, com $75 \%$ da população residindo no meio rural (Rostow, 1956).

Devido à limitação de sua produtividade, essas sociedades dedicam uma proporção extremamente elevada de seus recursos à agricultura. O que não é dedicado a essa atividade destina-se a atividades não produtivas, como guerras, conflitos religiosos e ao consumo excessivo da elite privilegiada. Ademais, verifica-se que a atitude das pessoas é conservadora e adversa, sendo que elas estão mais interessadas em aspectos religiosos e espirituais do que no mundo material ou físico. Desse sistema agrícola, originava-se uma estrutura social hierarquizada, com âmbito relativamente reduzido para a mobilidade vertical. Do ponto de vista da organização social, os vínculos de família e de clã exercem importante papel, enquanto que o poder político central tem seu centro de gravidade nas regiões, nas mãos dos que detinham a posse ou o controle da terra.

Em síntese, essa é uma sociedade caracterizada por emprego de métodos primitivos de produção na agricultura, pela falta da moderna ciência e tecnologia e por estar sujeita à operação da lei dos rendimentos decrescentes na agricultura ${ }^{8}$. A estrutura da sociedade é baseada na herança, na concentração de poder político nas mãos de grandes latifundiários e no crescimento populacional ao longo da linha malthusiana.

\footnotetext{
8 Rostow aponta Issac Newton como um marco que estabelece um mundo pré-newtoniano e pósnewtoniano. As sociedades tradicionais seriam pertencentes ao primeiro, dos quais são exemplos as dinastias da China, as Civilizações do Oriente Médio e Mediterrâneo e o mundo da Europa Medieval.
} 
2- As pré-condições para o arranco: etapa de transição em que uma sociedade se prepara - ou é preparada por forças externas - para o desenvolvimento sistemático. Observa-se que, nas sociedades tradicionais, os valores sociais, culturais e políticos estão postos e, assim, as iniciativas para o progresso econômico ou se originam na própria dinâmica ou surgem do cenário externo. Conforme Rostow (2010, p. 184), "[...] geralmente vinda de fora da sociedade, mas às vezes como resultado da própria dinâmica, surge a ideia de que o progresso econômico é possível. Essa ideia se propaga entre a elite estabelecida, ou mais frequentemente, entre algum grupo desprivilegiado [...]".

Ainda, segundo o autor, em grande parte dos casos, a busca pelo progresso econômico se alia aos motivos não econômicos tais como poder social e ambição política. Dissemina-se, portanto, a ideia de que não só é possível o progresso econômico, mas também que ele é condição indispensável. Essas novas ideias promovem a ampliação da educação (não necessariamente para todos), com o intuito de promover a adaptação à produção moderna. Os novos empreendimentos surgem motivados pela busca do lucro, principalmente no comércio, ampliando assim os mercados de produtos agrícolas, artesanais e importados, o que fortalece também as instituições que mobilizam o capital. Esse conjunto de investimentos fomenta o capital básico (infraestrutura), viabilizando o transporte dos insumos oriundos de outras nações, em grande parte financiado pelo capital estrangeiro. Enfim, ocorre um aumento nas taxas de investimentos produtivos, porém em uma base limitada de baixa produtividade e com instituições de valores retrógrados.

Segundo Cândido (1999), entre os elementos necessários capazes de criar o conjunto de pré-condições estão a existência de bancos, de infraestrutura (estradasde-ferro, comunicações) e a existência de espíritos empreendedores. Com as condições necessárias, é possível dar um salto de qualidade e progresso econômico, ou seja;

[...] Considerando que o país já reuniu as condições necessárias para dar um salto de qualidade, a ideia de progresso econômico aí aparece e se recobre de uma intensa positividade. O progresso é encarado como condição prévia para a realização da dignidade nacional. Nesse ponto, os sentimentos da população a respeito de seu país devem ser de orgulho. Além disso, ao nível do indivíduo, o sentido de futuro passa 
pelo sucesso econômico de seu país. Isto é, indivíduo e coletividade se encontram: o que a nação prepara para deixar como herança às gerações futuras é de algum modo o que cada um prepara para deixar a seus descendentes (CÂNDIDO, 1999, p. 06).

Essas pré-condições envolvem modificações em relação a vários aspectos da sociedade. Na política, ocorrem mudanças na estrutura organizacional, o que acaba produzindo um sentimento nacionalista no indivíduo (e na sociedade), unificando o território e tornando-o dinâmico economicamente. Por outro lado, o aumento da taxa de investimento requer uma mudança radical na atitude efetiva da sociedade perante a ciência fundamental e aplicada, dado o desencadeamento de mudanças nas técnicas de produção, bem como as novas condições e métodos de trabalho e os novos riscos e desafios a serem enfrentados.

Rostow (2010) define que o início da próxima etapa (o arranco) advém de um forte estímulo particular, sendo que ele pode ser consequência, por exemplo, da revolução política que afete o equilíbrio do poder social e os valores efetivos. Pode ser consequência, ainda, de uma inovação tecnológica, incluindo aquelas relacionadas ao setor de transportes, que estimule a cadeia secundária em setores modernos e que tenha efeitos nas economias externas. Ou também pode advir de um ambiente internacional novo e favorável (como foi o caso da abertura dos mercados britânicos e franceses na década de 1860$)^{9}$.

$O$ essencial nessa abordagem é o fato que o desenvolvimento anterior das sociedades possibilita uma resposta positiva, sustentada e autorreforçada aos estímulos da economia.

O resultado não é uma transformação preliminar nas funções de produção ou no volume de investimento, mas uma proporção mais elevada de aceitação de possíveis inovações num fluxo mais ou menos regular, assim como uma taxa de investimento mais elevada (ROSTOW, 2010, p. 186).

Por fim, ainda nesse período transitório, as condições necessárias (embora não suficientes) requerem o crescimento do setor industrial e dos lucros que, ao serem reinvestidos, induzem o desenvolvimento dos setores mais modernos da economia e

\footnotetext{
${ }^{9}$ Rostow (1978) identifica dois casos históricos em que ocorreram as pré-condições para o arranco: O primeiro, considerado o caso geral, adapta-se à evolução de grande parte dos países da Europa, em especial Inglaterra, como também a Ásia, o Oriente Médio, a África e a América Latina, enquanto o segundo compreende um pequeno grupo de nações que "nasceram livres", destacando-se Estados Unidos, Nova Zelândia, Canadá e Austrália. Ressalta-se, ainda, que, para o autor, o decisivo dessa fase é o aspecto político, sendo que a formação de um Estado nacional centralizado eficaz - baseado em coligações matizadas pelo novo nacionalismo, em oposição aos tradicionais interesses regionais agrários, à potência colonialista ou a ambos - foi um aspecto decisivo do período das pré-condições.
} 
amplia as novas técnicas de produção (tanto na indústria como na agricultura). Surge uma nova classe de empresários junto com novas possibilidades (necessidades) de exportação (importação).

3-O arranco $^{10}$ : nessa etapa, a resistência ao desenvolvimento é dissolvida e toda a sociedade entende que ele é necessário (situação normal). Com aproximadamente duas décadas de duração, esta é uma fase longa e cíclica (cada sociedade obedece a um período de maturação diferente) no que se refere ao processo de crescimento econômico sustentado, caracterizada também pela transformação na estrutura da economia (em consequência do aumento da acumulação de capital social fixo e de um surto de evolução tecnológica) e por mudanças no poder político da sociedade (criação de uma nova elite, de uma sociedade industrial moderna) ${ }^{11}$.

A agricultura deixa de ser conduzida de forma tradicional e passa a utilizar intensamente a mecanização (o aumento da produtividade agrícola acompanha a demanda dos centros urbanos). As indústrias reinvestem seus lucros para cobrir a depreciação dos equipamentos e atender à necessidade de ampliação da capacidade produtiva em decorrência do crescimento acelerado. Essas novas indústrias necessitam de serviços e de outros bens manufaturados e, assim, estimulam uma ulterior expansão das áreas urbanas e de outras instalações industriais modernas $O$ capital per capta aumenta e a taxa de crescimento é mantida pela inserção de novos setores na economia. Além disso, o setor industrial tende a ser inserido no comércio internacional.

São três as condições necessárias para a decolagem: i) uma taxa de investimento como proporção da renda superior a 10\%; ii) o desenvolvimento de um ou mais setores de manufatura básica e com elevadas taxas de crescimento (setores chaves) ${ }^{12}$; e, iii) a existência de uma estrutura política, social e institucional que auxilie na expansão do setor moderno, agregando um caráter contínuo ao crescimento ${ }^{13}$ (ROSTOW, 2010).

\footnotetext{
10 Tradução do termo take-off que, às vezes, é identificado também como decolagem. No texto, usamse os dois termos como sinônimos.

11 Rostow (1959) admite que a visão modernizante pode assumir formas de acomodação mútua, em vez da substituição dos tradicionais grupos pelos grupos mais modernos.

12 Historicament, os setores líderes nessa fase variam desde o setor de têxteis (algodão) na Inglaterra, as ferrovias nos Estados Unidos, França, Alemanha, Canada e Rússia. Adicionalmente, 0 processamento agrícola, óleo, as indústrias substitutivas de importações, a indústria da construção naval e a rápida expansão militar têm ajudado a promover o início do surto industrial (Rostow, 1959).

${ }^{13}$ Essa condição refere-se à capacidade dos países em mobilizar capitais oriundos de fontes internas. Segundo Rostow (2010), durante o processo de decolagem, países com Grã-Bretanha e Japão não importaram capital externo, enquanto países como Estados Unidos, Rússia e Canadá contaram com
} 
Ademais, a taxa de crescimento da economia seria determinada pelas diferentes taxas de crescimento setoriais, sendo que estes podem ser agrupados em três categorias, a saber: o setor de crescimento primário, que possibilita exploração e inovação e que colocam em movimento forças expansivas no restante da economia (em geral, utilizam-se das tecnologias existentes e aproveitam recursos até então inexplorados) e que, portanto, têm a capacidade de estimular os setores de crescimento suplementar (via efeitos de encadeamento para frente e para trás) como, por exemplo, carvão, ferro, e engenharia em função das estradas de ferro, e os setores de crescimento derivados, que são aqueles que se expandem mais ou menos em termos constantes em relação ao crescimento global da economia. Nos primeiros estágios do desenvolvimento, os setores de desenvolvimento primário e suplementar recebem seu impulso sobretudo da introdução e disseminação de modificações de atitudes quanto à oferta e aos custos, ao passo que os setores de desenvolvimento derivado se vinculam essencialmente às variações da procura.

4 - A marcha para a maturidade: etapa que ocorre em geral após 60 anos a partir do início da decolagem. Caracteriza-se pelo fato de que os frutos da ciência e da tecnologia se espalham por toda a economia. Cerca de 10 a 20\% da renda nacional são investidos continuamente, permitindo à produção ultrapassar regularmente o incremento demográfico. A economia se modifica rapidamente, e novas indústrias se aceleram e indústrias mais antigas se estabilizam.

Em outras palavras, é a etapa em que, dada a nova dinâmica do sistema, os principais setores da economia aproveitam as novas tecnologias e técnicas se voltam à produção de bens de consumo e serviços. A tecnologia moderna passa a ser empregada a todo o front da atividade econômica de tal forma que a economia se diversifica (ampliação e maior diversificação dos bens e serviços produzidos na economia nacional) (DUTRA, 2012).

Nessa etapa, ocorre uma modificação nos setores líderes da economia, transferindo a primazia das estradas de ferro, carvão e têxtil para o aço, a eletricidade, a química e os bens de capital complexos (Rostow, 1959). Ademais, a força de trabalho também se modifica em termos da sua composição, remuneração e aptidões. A massa de trabalhadores transita do trabalho agrário para os empregos em

um grande componente de capital estrangeiro. Outros países importaram capital externo e criaram condições prévias para a decolagem, porém não deram início a ela. São exemplos a Argentina antes de 1914; o Congo Belga (atual República do Congo) e a Venezuela. Independentemente da importação ou não de capital, é necessário para a decolagem a capacidade de mobilizar, de forma produtiva, a poupança interna, bem como uma estrutura que viabilize uma maior taxa marginal de poupança. 
escritórios e nas indústrias. A porcentagem de trabalhadores no campo, que na etapa anterior estava situada entre 60 e $70 \%$, diminui para o nível situado entre $40 \%$ a 20\%. O setor terciário agrega valor.

Podemos definir essencialmente a maturidade como a etapa em que a economia demonstra capacidade de avançar para além das indústrias que inicialmente lhe impeliram o arranco e para absorver e aplicar eficazmente num campo bem amplo de seus recursos - se não a todos eles - os frutos mais adiantados da tecnologia (então) moderna. Esta é a etapa em que a economia demonstra que possui as aptidões técnicas e organizacionais para produzir não tudo, mas qualquer coisa que decida produzir. Pode carecer (como a Suécia e a Suíça contemporâneas, por exemplo) das matérias-primas ou de outros fatores de suprimento necessários para produzir economicamente um determinado tipo de produção; sua dependência, toda via, é antes uma questão de opção econômica ou de prioridade política do que uma carência tecnológica ou institucional (ROSTOW, 1978, p. 22 e 23).

Por fim, investimento cada vez maior em educação faz surgir uma grande máquina burocrática de sociedades anônimas e a competitividade exacerbada vem acompanhada do desejo de bem-estar e segurança. Ou seja, a força de trabalho emergente é não só susceptível de organizar-se com o aumento da eficácia dos mercados de trabalho, mas também percebe que a civilização industrial do qual ela é uma parte pode oferecer níveis e tipos de consumo, antes não considerados como uma possibilidade realista. O aumento da renda real per capita torna-se essa possibilidade efetiva. Além disso, a nova força de trabalho, cada vez mais nascida nas cidades, em vez de transferida do meio rural, percebe o seu "peso" no processo político, de tal forma que o governo se vê mais e mais impelido a empreender medidas de segurança social e econômica (PARR, 2001).

5 - A era do consumo de massa: fase em que a economia se direciona para o consumo de massa, onde florescem as indústrias produtoras de bens de consumo duráveis e o setor de serviços assume preponderância dentro da estrutura setorial da economia do país. Segundo Rostow (1978), à proporção que as economias atingiram a maturidade, duas coisas aconteceram: a renda per capita superou as cifras anteriores (de tal forma que um maior número de pessoas conseguiu, como consumidores, ultrapassar as necessidades mínimas de alimentação, habitação e vestuário) e a estrutura da força de trabalho modificou-se de maneira tal, que não só 
aumentou a população urbana em relação à total, mas também a de trabalhadores em escritórios ou como operários especializados (em grande parte vinculados ao setor de serviços).

Uma característica marcante nessa fase é a acumulação de um excedente econômico significativo. Ou seja, a economia experimenta o surgimento de inúmeras novas indústrias e uma inédita expansão do comércio internacional. A sociedade tem várias opções "abertas", como a extensão dos programas de assistência social (busca pelo Estado de Bem-Estar), a luta por maior poder e prestígio mundial bem como a realização de investimentos no exterior envolvendo a exportação de capital e a perícia técnica; e, finalmente, a engrenagem da economia em torno de padrões específicos de consumo. As primeiras três possibilidades geralmente resultam em um prolongamento da fase anterior, enquanto a última envolve entrar na fase de consumo de massa propriamente dito.

Em termos setoriais, a Tabela 1 mostra a mudança estrutural implícita ao longo das etapas do desenvolvimento. Como observado, o setor primário predomina nas duas primeiras, enquanto o setor secundário (indústria) tem papel fundamental nas duas etapas subsequentes. Por fim, na quinta etapa, o setor terciário exerce primazia.

Tabela 1 - Composição setorial e mudança estrutural ao Longo das Etapas do Desenvolvimento

\begin{tabular}{l|l|l|l}
\hline & $\begin{array}{l}\text { Setor } \\
\text { Primário }\end{array}$ & Setor Secundário & Setor Terciário \\
\hline Sociedade Tradicional & $\begin{array}{l}\text { Grande } \\
\text { maioria }\end{array}$ & Muito pouco & Muito pouco \\
\hline $\begin{array}{l}\text { Pré-condições para o } \\
\text { arranco }\end{array}$ & $\begin{array}{l}\text { Grande } \\
\text { maioria }\end{array}$ & Pouco & Muito pouco \\
\hline O Arranco & Declínio & $\begin{array}{l}\text { Rápido } \\
\text { crescimento }\end{array}$ & Muito pouco \\
\hline A marcha para a maturidade & Pouco & Estável & $\begin{array}{l}\text { Rápido } \\
\text { crescimento }\end{array}$ \\
\hline A era do consumo em massa & Muito pouco & Declínio & Grande maioria \\
\hline Fonte: Adaptado de Waugh (2009)
\end{tabular}

De uma perspectiva histórica, a Figura 2 expõe os estágios de desenvolvimento de Rostow (1978), fazendo relação com o período em que alguns países vivenciaram cada uma desses estágios. A experiência britânica, por exemplo, com o nascimento 
de grandes inventores, revolucionou a tecnologia. $\mathrm{Na}$ abertura com o mundo externo, Rostow utiliza o exemplo japonês enquanto que, para elucidar os exemplos de revoluções políticas que objetivavam a mudança, são citados os casos da Rússia, com a revolução Bolchevique de 1917 e a revolução Chinesa de 1911. O caso americano da década de 1960 é utilizado para mostrar uma sociedade que vivenciou uma era de consumo em massa (OLIVEIRA et all, 2013). Figura 2 - 0 modelo de desenvolvimento econômico de Rostow aplicado a
alguns países

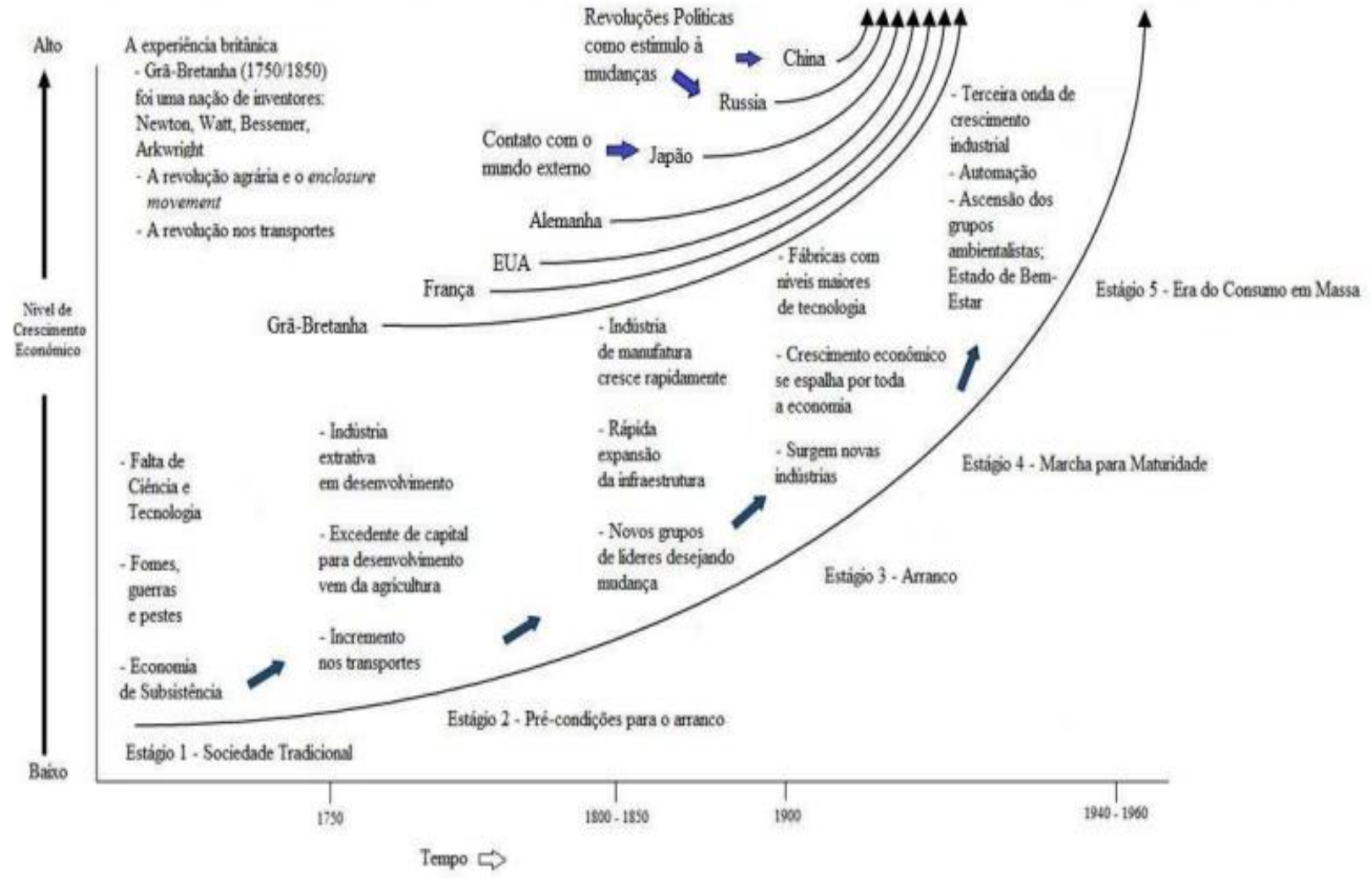

Fonte: Eberhardt (2013)

Convém ressaltar, ainda, que o conceito de desenvolvimento econômico, para Rostow, é caracterizado por seis fatores (Guimeiro, 2012; Sarmento, 2008; Dutra, 2012):

(i) o nível de produção de uma economia é resultante do volume da força de trabalho, do seu estoque de capital (poupança) e do seu acervo de conhecimentos aplicados; 
(ii) a taxa de crescimento da economia depende da variação da força de trabalho, da poupança e do conhecimento tecnológico;

(iii) as taxas de variações dependem da interação de rendimentos técnicos e da efetividade das seguintes proposições em instituições econômicas, sociais e políticas da sociedade: propensão de aplicar a ciência na economia; propensão de aceitar as inovações; propensão de obter progressos materiais; propensão ao consumo; propensão a ter filhos;

(iv) as transformações são chamadas de propensões e são previstas a longo prazo pelas forças econômicas, sociais e políticas, que determinam a estrutura social, as instituições e a política efetiva da sociedade;

(v) as propensões que estão vinculadas às decisões econômicas devem ser avaliadas além destas proposições econômicas;

(vi) caso aconteça uma desaceleração na economia, ela pode influenciar negativamente na qualidade da força de trabalho nas indústrias extrativas e nos investimentos no setor agrícola e industrial.

Ademais, o desenvolvimento econômico, na concepção de Rostow (1956), compreende três fases: um período longo (um século), onde são reunidas as precondições para a decolagem; a decolagem propriamente dita (definida em uma ou duas décadas); e um período prolongado no qual o crescimento se torna relativamente automático. Segundo o autor, é preciso passar pelas três fases para estabelecer a decolagem em um país atrasado economicamente.

A ferramenta metodológica utilizada por Rostow para medir o grau de desenvolvimento econômico dos países é a "decolagem". Assim, o conceito de decolagem parte de três condições inter-relacionadas: 1) incremento na taxa de investimento produtivo (de $5 \%$ ou menos para mais de $10 \%$ da renda nacional); 2) desenvolvimento de um ou dois setores manufaturados básicos; 3) A existência ou a rápida eclosão de um arcabouço político, social e institucional que aproveite os impulsos expansionistas do setor moderno vindo de fora, de modo que o acompanhe internamente (ROSTOW, 1978, p. 55-56). 
Entrementes, a fase de maior relevância rumo ao desenvolvimento é o take-off (arranco). Ou seja, é nesse momento que as economias alcançam o ponto crucial para o desenvolvimento, onde se soltam as amarras que o reprimem, impulsionando-se, assim, o crescimento e a modernização (SARMENTO, 2012).

Rostow relaciona fatores sociais e institucionais com as forças econômicas de crescimento por meio de uma série de tendências observáveis da comunidade, a saber: i) propensão a desenvolver a ciência fundamental; (2) propensão para aplicar a ciência para as necessidades económicas; (3) propensão para aceitar inovações; (4) propensão a buscar avanço material; (5) propensão a consumir; e, (6) propensão ter filhos. Estas propensões dependem das atitudes, das motivações e das aspirações do povo, que, por sua vez, dependem dos fatores políticos, econômicos e sociais anteriores. A utilização destas propensões para explicar a quantidade e a qualidade do trabalho e do capital disponível em uma economia envolve, em última análise, o entendimento de que o desenvolvimento econômico depende tanto de fatores econômicos como de não econômicos.

Por fim, convém ressaltar que as proposições de Rostow foram muito contestadas. As críticas foram direcionadas tanto à credibilidade das divisões em etapas, aos seus dados e à sua análise agregada, como ao seu alinhamento político com os Estados Unidos da América. Alguns críticos deram à sua obra o rótulo de receituário simplista, destinado à doutrinação das economias capitalistas pobres para a inevitabilidade do triunfo capitalista sobre o adversário socialista (Sarmento, 2012). Segundo Cândido (1999), "A teoria de Rostow é, portanto, um produto intelectual concebido para enfrentar as interpretações de esquerda"14.

Ainda, para Moraes e Silva (2010), a obra de Rostow é uma generalização arbitrária e restrita da marcha da história moderna. Ademais, os traços que diferenciam as etapas ou são confusos ou, quando mais nítidos, encerram visíveis arbitrariedades. A distinção entre a evolução econômica antiga e moderna e a separação entre o estágio de pré-condição de desenvolvimento e o estágio de desenvolvimento é feita com a ausência de caracterizações precisas. Ademais, a precedência ou a sucessão no tempo não caracteriza os estágios (BULHÕES, 1960; ITAGAKI, 1963).

\footnotetext{
${ }^{14}$ Ao invés dos estágios do determinismo marxista, feudalismo, burguesia mercantil, capitalismo industrial e socialismo, teríamos independentemente de sistemas ideológicos, a transmutação da sociedade tradicional para a sociedade transicional. Nesta se processaria a "arrancada para o desenvolvimento" passando-se em seguida à sociedade industrial madura e à civilização de autoconsumo. Ver Campos (1994).
} 


\section{Etapas do Desenvolvimento: uma aplicação}

Nessa seção, para cumprir com o objetivo do trabalho, realiza-se uma aplicação do modelo rostowiano para o município de Três Lagoas-MS. É necessário, contudo, ressaltar os problemas adicionais que este exercício enfrenta uma vez que a teoria de crescimento de Rostow estava principalmente preocupada com a economia nacional. Ou seja, ainda que existam mais do que umas poucas referências às regiões na análise do autor, elas não foram exploradas em detalhes. Portanto, a preocupação e o desafio do exercício proposto é aplicar e mostrar a relevância da análise de Rostow em uma escala regional.

Em outras palavras, de uma perspectiva regional, não há nada a priori que estabeleça que o desenvolvimento dentro de uma nação será necessariamente válido em nível regional. Ou ainda, as etapas de desenvolvimento de Rostow, propostas inicialmente para o contexto de uma economia nacional, não necessariamente devem ser encontradas em nível regional. Na verdade, como mostra Parr (2001), existem exemplos para ambas as situações: regiões onde o desenvolvimento segue as etapas propostas por Rostow - são exemplos regiões particulares da Europa (como a Westphalia na Alemanha e a Scotland Central e o Noroeste da Inglaterra) e partes antigas dos Estados Unidos (New England e os estados do meio-Atlântico); e regiões onde essa metodologia etapista é aplicada com dificuldade - são exemplos regiões especialmente dentro dos chamados "novos países" (países de colonização europeia).

No caso em que o modelo etapista é aplicado com dificuldade, o problema aparece em linha com a natureza do critério usado para definir os vários estágios. Por exemplo, para muitas regiões individuais, na fase de constituição das pré-condições para o arranco, o critério de Rostow não se aplica ou não é relevante. Este foi certamente o caso no que diz respeito à modernização da agricultura. $\mathrm{Na}$ abertura do Centro-Oeste e, mais tarde, nas grandes planícies nos Estados Unidos, por exemplo, modernas técnicas agrícolas foram aplicadas, enquanto que, para outras regiões, cujo 
crescimento subsequente foi baseado em silvicultura ou na mineração, a modernização da agricultura foi relativamente sem importância.

Nesse mesmo sentido, a exigência de Rostow de que a fase de decolagem é caracterizada pela emergência de um setor líder ligado à atividade manufatureira capaz de gerar incentivos para economia por meio de efeitos indiretos nem sempre é simplesmente refletida em escala regional. Muitas regiões alcançam a decolagem sem a emergência de um setor líder ligado à manufatura. Neste contexto, North (1955) argumentou que o determinante fundamental dessas regiões é ao estabelecimento bem-sucedido de uma base de exportação, independentemente de isso envolver ou não a manufatura. Isto sugere que, em escala regional, o setor líder no sentido de Rostow pode ser interpretado como o elemento dominante da base de exportação. É provável que a sofisticação e a liderança tecnológica dependam da expansão desse elemento.

Outro problema apontado por Parr (2001) relaciona-se ao fato de que, enquanto o setor líder deve (como requerido) ter um impacto indireto sobre a economia regional, isso em grande parte envolve o desenvolvimento de setores de "crescimento derivado" (atividades com finalidade regional, que apóiam o setor líder) e não nos setores "de crescimento suplementar" com base em ligações inter-indústria. Tais ligações para o setor líder da economia regional poderiam ter surgido neste momento, e seriam de caráter inter-regional. A possibilidade, mesmo a probabilidade desta conexão externa do setor líder na fase de descolagem regional representa um afastamento significativo da etapa de decolagem em termos da economia nacional de Rostow, onde tais ligações são predominantemente internas.

Por fim, ressaltamos a necessidade de se levar em consideração quando da análise desse exercicio da essencialidade das distinções temporais e das próprias etapas em comparação ao trabalho original de Rostow, sobretudo por conta das transformações tecnológicas ocorridas, que modificam a temporalidade e a formatação dos investimentos industriais, além de encurtar o tempo de maturação e de promover novas alternativas na construção da infraestrutura imprescindível ao desenvolvimento industrial. 
Fica evidente, portanto, que, se a estrutura de Rostow é aplicada no nível regional, é necessário que as etapas sejam definidas em termos mais gerais, a fim de acomodar a natureza distinta dessas economias e as diferentes formas que o desenvolvimento regional pode tomar. Portanto, a caracterização proposta a seguir do desenvolvimento de Três Lagoas leva em consideração esses aspectos, resguardando, evidentemente, as particularidades históricas.

\section{2 - A sociedade tradicional de Três Lagoas}

O resgate da história econômica do município de Três Lagoas permite a caracterização da sua sociedade tradicional. Em 1829, a chegada do sertanista Joaquim Francisco Lopes e, posteriormente, dos bandeirantes marca o início da história do município, que, nessa época, pertencia à cidade de Paranaíba (OLIVEIRA, 2006).

Em 1899, foram descobertas as três lagoas, como consequência do fluxo comercial que se estabeleceu a partir do comércio de sal e mercadorias que vinham pelo rio Tietê. Esse incipiente comércio atraiu posseiros e criadores de gado para a região. Entre 1902 a 1905, começaram a surgir estabelecimentos comerciais e diversas benfeitorias em grande parte como decorrência da venda de gado que crescia localmente, dando origem ao primeiro ciclo econômico da região.

Em outras palavras, desde os primórdios da sua colonização/ocupação, o município de Três Lagoas teve como principal atividade o manejo de gado associado a atividades subsidiárias como a agricultura familiar. Subsequentemente, a pecuária se fortaleceu como principal atividade econômica da região, em decorrência das favoráveis condições que ali existiam/emergiam, especialmente no que se refere às grandes pastagens e à densidade do comércio (de compra e venda de animais). Nesse contexto, o maior desenvolvimento dessa atividade acaba por atrair uma corrente migratória de sertanistas para a região.

Ademais, nesse período, após o início das obras da estrada de ferro Noroeste do Brasil, a região recebeu um novo impulso, ou seja,

o sucesso que alcançaram como criadores de gado proporcionou a atração de muita gente e a região foi sendo colonizada. A facilidade de comunicação com o posto avançado de Itapura e com o ramal da 
Estrada de Ferro Noroeste do Brasil contribuiu para fazer da região um ponto de atração [...] (OLIVEIRA, 2006, p. 42).

A construção da estrada de ferro Noroeste do Brasil favoreceu a migração para a região. Por exemplo, em 1911, instalou-se na região um grupo de engenheiros, formando um povoado que, em 1915, se transformou na vila de Três Lagoas e, posteriormente, no município de Três Lagoas (em 1920).

O desenvolvimento da pecuária foi acelerado e provocou muitas mudanças no contexto urbano e rural. Neste primeiro ciclo econômico, ocorreram algumas modificações que vão posteriormente alavancar o desenvolvimento da região, como a melhoria na infraestrutura relacionada à água, à energia, à comunicação e ao transporte e, também, no que se refere à dinâmica comercial, especialmente no tocante às pequenas empresas.

\section{3 - Três Lagoas e as pré-condições para o arranco}

A instituição das pré-condições para o arranco em Três Lagoas podem ser identificadas na estruturação ferroviária, rodoviária e hidroviária. Ademais, o incentivo político foi fundamental nesta etapa.

Segundo Pavão (2005), a cidade de Três Lagoas surge a partir da construção da estrada de ferro Noroeste do Brasil inaugurada em 1915. A construção da estrada iniciou-se em 1905 ligando inicialmente as cidades de Corumbá, Campo Grande e Três Lagoas e, em 1943, ligou também a cidade de Ponta Porã, no Sul do estado. A construção demandou força de trabalho e a estrada fomentou a economia da região. Nesse período, o município passou a ocupar a quarta posição em termos de contingente populacional urbano.

Segundo Pavão (2005, p. 142):

Em relação ao número de estabelecimentos industriais por município do Sul de Mato Grosso e o capital aplicado, para o ano de 1940, apresentava o seguinte: Aquidauana (15/675\$), Bela Vista (9/350\$), Campo Grande (67/9:388\$), Corumbá (35/12:201\$), Maracaju (6/174\$), Miranda (4/2:253\$), Ponta Porã (112/14:470\$), Porto Murtinho (11/24.576\$), Três Lagoas (14/474\$), e a capital Cuiabá $(52 / 5.743 \$)$ 
A partir da década de 1950, o cenário econômico nacional influencia sobremaneira o desenvolvimento da região. A literatura reconhece que, após esse período, a economia brasileira passa pelo processo de industrialização com a produção de bens duráveis, como carros e caminhões. Ademais, essa industrialização passou a exigir investimentos em infraestrutura e logística para fins de transporte. Em outras palavras, o crescimento da economia nacional, especialmente da Região Sudeste - berço da industrialização - demandou uma série de modificações que acabaram afetando as demais economias regionais. No caso do Centro-Oeste e, mais especificamente, da região de Três Lagoas, a ação do governo federal a partir da promoção de programas para o desenvolvimento buscou incorporar essas regiões à economia nacional e, assim, ampliar a ocupação e levar o desenvolvimento a elas.

Entre as ações, destacam-se o Plano de Metas (1956-1960) implantado no governo de Juscelino Kubitschek, que beneficiou o Sul do Mato Grosso com a implantação de rodovias que cruzavam o estado nos quatro pontos. Nesse caso, Três Lagoas foi beneficiada com a rodovia BR 262 ligando-a até as cidades de Corumbá e Campo Grande, algumas das principais cidades e polos de desenvolvimento da região.

Posteriormente, com o II Plano de Desenvolvimento Nacional (1975-1979), através do Programa de Desenvolvimento dos Cerrados (Polocentro), ocorreu uma série de investimentos na atividade agropecuária, em grande parte via crédito rural, e em infraestrutura, especialmente nas cidades de Água Clara, Brasilândia, Campo Grande e Três Lagoas. Abreu (2001) destaca que os recursos do Polocentro viabilizaram os investimentos em transporte, com o melhoramento dos trechos que ligavam Campo Grande a Três Lagoas.

Em 1974, finalizou-se a construção da usina de Jupiá, cujo início data de 1960. O governo do estado de São Paulo foi o responsável pela obra e possibilitou o fornecimento de energia elétrica para parte do estado sul-mato-grossense. Esta construção, a exemplo da construção da ferrovia, promoveu grande fluxo migratório e atraiu várias empresas para o município de Três Lagoas. Segundo Pavão (2005),

Sem sombra de dúvida um dos principais fatores do desenvolvimento da cidade foi o advento da construção das Barragens Engenheiro de Souza Dias, em Jupiá, que teve início em 1958 e foi concluída em 
1974, sendo composta por 14 geradores, com potência de 100.000 KW, e a de Ilha Solteira, com 20 geradores e potência 160.000 KW, no período de 1968 a 1978 (OLIVEIRA, 2006, p. 43).

Outro marco relevante do início da década de 1970 foi a valorização das terras em Três Lagoas, em grande parte como resultado dos programas estratégicos do Governo Federal para a pecuária, que tinha entre outras a finalidade de estimular a ocupação produtiva de certos territórios. A expansão da pecuária teve como consequência grande impacto ambiental no cerrado. No final da década de 1970, o Governo Federal incentivou o reflorestamento da região e incentivou a instalação de empresas desse setor no intuito de, também, criar empregos nesta área. Empresas como o Grupo Norte Americano Champion investiram em terras de reflorestamento de pinheiros e eucalipto (OLIVEIRA, 2006).

Para Oliveira (2006), as instalações da Usina Hidrelétrica de Jupiá, assim como a empresa Champion, que será adquirida pela multinacional "International Paper", tiveram grande importância no progresso e foram os propulsores do desenvolvimento do município.

A concentração de investimentos no município de Três Lagoas deve-se em grande parte à sua localização estratégica, na divisa com o estado de São Paulo, que é importante rota para o escoamento de mercadorias para as demais regiões.

[...]. Seguindo a tradição da economia local, tornou-se um local de produção pecuária, entretanto, a partir de1974, com a construção da Usina de Jupiá, apresenta-se como o município com grande investimento industrial, principalmente a partir da implantação das leis de incentivos fiscal do Governo (1984-1997), devido à proximidade com o mercado do interior de São Paulo, Minas Gerais e Goiás, energia farta e incentivos municipais importantes (PAVÃO, 2005, p. 171).

Ainda como parte da criação das pré-condições, destaca-se a política de incentivos governamentais (federal e municipal) para Três Lagoas, que ocorreram no período de 1984 a 1997. Esses incentivos visavam facilitar a instalação de empresas e indústrias na cidade. Nesse esforço de atração de investimentos industriais para o município destaca-se a vinda do Gasoduto Brasil-Bolívia (Gasbol) (o gás oriundo da 
Bolívia passa por Campo Grande, Corumbá, e Três Lagoas). O Gasbol é um investimento federal e tem como proposta mudar a matriz energética da região.

Em síntese, a existência de incentivos e de infraestrutura energética, somados à localização estratégica do município, viabilizaram as pré-condições para a industrialização do município, especialmente a partir de 1997. Essas modificações acompanham (ou são acompanhadas) de mudanças no cenário internacional, especialmente com o deslocamento da produção global em direção aos países da Ásia e, principalmente, com o ciclo de expansão e valorização das commodities puxados pelo elevado crescimento chinês na primeira década do século corrente. Soma-se a isso a emergência, em termos municipais, de uma nova classe de empresários (industriais) com novas possibilidades e necessidades em relação ao comércio exterior.

Por fim, cumpre ressaltar algumas modificações no âmbito político e social. Segundo Rostow, nessa fase algumas mudanças podem ocorrer e favorecer o estabelecimento das pré-condições, como, por exemplo, a busca pelo progresso econômico alia-se a motivos não econômicos tais como poder social e ambição política e/ou ocorrem modificações que afetam o equilíbrio do poder social e os valores efetivos. Nesse caso, vale ressaltar que os grupos políticos e as classes sociais dominantes em Três Lagoas sempre estiveram ligados ao grupo dos produtores rurais (sobretudo aquele representado pelos pecuaristas) e, em menor grau, o dos grandes comerciantes e prestadores de serviços. Isso pode ser verificado uma vez que, reconhecidamente, são os representantes desses grupos que ocuparam ao longo da história posições dentro dos poderes eletivos, legislativo e executivo municipal.

Considerando que, desde o final dos anos 1990, houve significativo aumento da atividade industrial no município, era de se esperar a emergência de conflitos pela recolocação hegemônica das frações de classes, especificamente entre frações dominantes tradicionais e o grupo dos investidores industriais. Contudo, com base na análise da sociedade três-lagoense, conclui-se que, nesse caso específico, não houve um acirramento nesse conflito. Pelo contrário, observa-se uma consensual defesa em prol da industrialização do município. Jurado (2008) aponta três fatores que permitem elucidar tal situação: i) os resultados financeiros alcançados com a especulação 
imobiliária e com a prestação de serviços, que garantiram aos grandes proprietários urbanos lucros elevados; ii) os resultados financeiros com a especulação imobiliária rural - quando reconhecidamente o advento da industrialização, especialmente no caso das empresas que necessitam de grandes áreas para a produção do seu substrato produtivo (madeira de reflorestamento), elevou o preço médio da terra significativamente e, dessa forma, beneficiou os proprietários rurais; e, iii) os efeitos eleitorais positivos, uma vez que as disputas eleitorais são marcadas por candidatos que buscam vincular-se como sendo partícipe do condicionamento institucional da industrialização local.

\section{4 - Três Lagoas no rumo da decolagem?}

O município de Três Lagoas estruturou dois distritos industriais e articula a implantação de um terceiro ${ }^{15}$. Segundo Francisco (2013), o primeiro distrito industrial teve início em 1980, porém sua localização em terreno inadequado inviabilizava a instalação das empresas, dificultando a criação de infraestrutura e prejudicando a sua produtividade. O local foi transformado em um cinturão verde, com o intuito de fomentar a produção de hortifrutigranjeiros e a produção familiar.

O distrito industrial II, por sua vez, possui localização estratégica, com conexão para escoamento logístico e próximo à saída para São Paulo. Além disso, os terrenos são planos, o que viabiliza a criação de infraestrutura necessária para as indústrias. O distrito industrial II abriga grandes empresas como Cargill Agrícola S.A, Fibria Papel e Celulose e Eldorado Brasil, que contam com terminais próprios de embarque e desembarque de composições hidroviárias, o que facilita o escoamento em grande escala, principalmente até o Porto de Santos - SP.

A industrialização de Três Lagoas teve início com a construção da indústria de alimentos Mabel, em 1998. A chegada desta indústria fez com que os empreendedores locais se modernizassem, para atender às demandas da empresa $\mathrm{e}$ da economia local (XAVIER, SANTOS, ALCALDE, DE SOUZA, 2007).

Pereira e Gomes (2004) destacam que, a partir de 1997, o município implementou uma política de atração das indústrias que, de alguma forma, foi favorecida pelo processo de descentralização industrial dos grandes centros. Foram oferecidas isenções fiscais e infraestrutura para a instalação das novas empresas. Na

\footnotetext{
${ }^{15}$ Nesse distrito está prevista a construção da Unidade de Fertilizantes Nitrogenados Três Lagoas, indústria custeada pela Petrobrás.
} 
esfera municipal, garantiu-se a isenção do Imposto Predial e Territorial Urbano (IPTU), Imposto Sobre Serviços (ISS) e demais taxas, além da doação de boa parte da infraestrutura.

Na esfera estadual, de acordo com Pereira e Gomes (2004, p. 55):

[...] O Estado, por sua vez, concede às indústrias incentivo fiscal equivalente à isenção de $67 \%$ do ICMS, gerado pela comercialização dos seus produtos por um prazo de 7 (sete) anos, podendo prorrogar por até 10 (dez) anos. Além, disso em virtude da natureza do setor, há postergação por mais 7 (sete) anos, com abatimento de $50 \%$ do valor original e redução de $30 \%$ do índice de correção.

A instalação de diversas indústrias atraiu para o município a Federação das Indústrias de Mato Grosso do Sul, que passa a atuar com o Serviço Nacional de Aprendizagem Industrial (SENAI), Serviço Nacional de Aprendizagem Comercial (SENAC), Serviço Brasileiro de Apoio as Micros e Pequenas Empresas (SEBRAE) e Serviço Social da Indústria (SESI), com intuito de qualificar a mão de obra local com ensino técnico e profissionalizante (OLIVERA, 2006).

Diante dos incentivos econômicos e da concentração de instituições que atuam no fomento da produção industrial, Três Lagoas vem se consolidando como um importante polo industrial. A Tabela 2 mostra os principais setores industriais levando em consideração o número de estabelecimentos presentes no município. Conforme pode ser observado, o número de estabelecimentos cresceu significativamente (variação positiva superior a $200 \%$ ), sendo que o destaque foi o crescimento da indústria da construção e de produtos alimentícios. Já a Tabela 3 apresenta a participação em termos estaduais do número de estabelecimentos dos referidos setores. Observa-se que o município concentra parcela significativa da indústria de celulose, seguida da indústria metalúrgica e de alimentos. 
Tabela 2 - Setores industriais e número de estabelecimentos em Três Lagoas, 2007-2014.

\begin{tabular}{|c|c|c|c|c|c|c|c|c|c|}
\hline & 2007 & 2008 & 2009 & 2010 & 2011 & 2012 & 2013 & 2014 & variação \\
\hline Indústria de Celulose, Papel e Produtos de Papel & 6 & 6 & 9 & 9 & 7 & 12 & 12 & 13 & 117 \\
\hline Indústria de Confecção de Roupas e Artigos do Vestuário, Exceto Roupas Íntimas & 6 & 6 & 6 & 9 & 11 & 17 & 19 & 22 & 267 \\
\hline Indústria da Construção de Edifício & 7 & 11 & 14 & 17 & 35 & 46 & 54 & 64 & 814 \\
\hline Indústria Diversas & 12 & 10 & 8 & 17 & 27 & 36 & 44 & 48 & 300 \\
\hline Indústria de Impressão e Reprodução de Gravações & 12 & 12 & 14 & 15 & 15 & 17 & 19 & 23 & 92 \\
\hline Indústria Metalurgia, Exceto Máquinas e Equipamentos - Outros Produtos de Metal & 11 & 15 & 16 & 18 & 22 & 24 & 30 & 31 & 182 \\
\hline Indústria de Móveis com Predominância de Madeira & 3 & 4 & 4 & 6 & 6 & 9 & 12 & 13 & 333 \\
\hline Indústria de Produtos Alimentícios - Outros & 6 & 10 & 10 & 14 & 24 & 29 & 35 & 38 & 533 \\
\hline Indústria de Produtos Borracha e de Material Plástico & 17 & 19 & 19 & 20 & 21 & 20 & 20 & 20 & 18 \\
\hline Indústria de Produtos Têxteis Diversos & 10 & 10 & 8 & 9 & 12 & 13 & 20 & 20 & 100 \\
\hline Total & 90 & 103 & 108 & 134 & 180 & 223 & 265 & 292 & 224 \\
\hline
\end{tabular}

Fonte: Semade (2016)

Tabela 3 - Participação em termos estaduais do número de estabelecimentos dos setores industriais de Três Lagoas, 2007-2014.

\begin{tabular}{|c|c|c|c|c|c|c|c|c|}
\hline & 2007 & 2008 & 2009 & 2010 & 2011 & 2012 & 2013 & 2014 \\
\hline Indústria de Celulose, Papel e Produtos de Papel & 19,4 & 24,0 & 26,5 & 21,4 & 17,5 & 20,3 & 21,8 & 22,0 \\
\hline Indústria de Confecção de Roupas e Artigos do Vestuário, Exceto Roupas Íntimas & 4,5 & 3,9 & 2,9 & 3,0 & 2,7 & 3,5 & 3,4 & 3,5 \\
\hline Indústria da Construção de Edifício & 6,7 & 8,7 & 8,8 & 7,8 & 11,3 & 9,7 & 8,1 & 8,1 \\
\hline Indústria Diversas & 6,2 & 4,7 & 3,4 & 5,8 & 7,6 & 8,7 & 9,3 & 8,2 \\
\hline Indústria de Impressão e Reprodução de Gravações & 5,0 & 4,7 & 5,3 & 5,3 & 4,9 & 5,0 & 5,1 & 5,9 \\
\hline Indústria Metalurgia, Exceto Máquinas e Equipamentos - Outros Produtos de Metal & 11,3 & 15,5 & 14,4 & 11,5 & 11,5 & 10,3 & 10,8 & 10,5 \\
\hline Indústria de Móveis com Predominância de Madeira & 2,9 & 3,7 & 3,2 & 4,2 & 3,0 & 3,5 & 3,9 & 3,6 \\
\hline Indústria de Produtos Alimentícios - Outros & 4,4 & 6,4 & 5,3 & 5,3 & 7,8 & 7,7 & 7,8 & 7,9 \\
\hline Indústria de Produtos Borracha e de Material Plástico & 14,5 & 13,3 & 9,4 & 8,7 & 9,4 & 9,1 & 13,2 & 11,6 \\
\hline Indústria de Produtos Têxteis Diversos & 32,3 & 33,3 & 25,8 & 13,6 & 13,2 & 10,9 & 13,0 & 11,8 \\
\hline Total & 2,8 & 3,1 & 2,9 & 3,0 & 3,5 & 3,8 & 3,9 & 3,9 \\
\hline
\end{tabular}

Fonte: Semade (2016).

\subsection{1 - Desempenho econômico recente de Três Lagoas ${ }^{16}$}

Apresenta-se, a seguir, uma série de dados relativos ao desempenho econômico de Três Lagoas que buscam fundamentar as considerações sobre a atual fase de desenvolvimento do município e que suportam a hipótese de que ela se encontra na fase inicial do processo de decolagem.

Inicialmente, para fins de comparação, a Tabela 4 mostra a composição setorial do PIB do estado de Mato Grosso do Sul. É possível observar que o setor da agropecuária mantém no estado ainda forte participação (embora com tendência

\footnotetext{
${ }^{16}$ A Secretaria de Estado de Meio Ambiente e Desenvolvimento Econômico (Semade) divulgou uma nova série resultante dos estudos de Contas Regionais tendo como referência o ano de 2010, em substituição à série anterior, que estava referendada no ano de 2002. Portanto, os dados apresentados para o período 2010-2013 (quando apresentados exclusivamente neste período) referem-se a essa "nova série".
} 
decrescente) em comparação ao Brasil ${ }^{17}$ e que o setor industrial ganhou participação, especialmente para os últimos anos analisados.

Tabela 4 - Participação por grande setor no valor adicionado do MS, 2003-2013 (em \%)

\begin{tabular}{c|c|c|c}
\hline Anos & Primário & Secundário & Terciário \\
\hline 2003 & 24,72 & 15,7 & 59,58 \\
\hline 2004 & 20,93 & 19,21 & 59,86 \\
\hline 2005 & 15,45 & 17,24 & 67,31 \\
\hline 2006 & 14,53 & 18,46 & 67,01 \\
\hline 2007 & 15,8 & 16,68 & 67,52 \\
\hline 2008 & 16,6 & 17,64 & 65,76 \\
\hline 2009 & 15,53 & 18,48 & 65,99 \\
\hline 2010 & 17,23 & 22,6 & 60,16 \\
\hline 2011 & 17,53 & 22,64 & 59,82 \\
\hline 2012 & 17,72 & 22,56 & 59,72 \\
\hline 2013 & 17,75 & 22,16 & 60,09 \\
\hline
\end{tabular}

Fonte: IBGE/CONAC, SEMADE

Considerando o desenvolvimento regional a partir da participação das microrregiões no valor adicionado (Tabela 5), observa-se que a microrregião de Campo Grande (que abriga a capital do estado) mantém a maior participação (relativamente constante ao longo do tempo). O que se destaca é Três Lagoas que, junto com a microrregião do Baixo Pantanal, foram as que mais ganharam participação no período analisado.

Tabela 5 - Participação das microrregiões no valor adicionado de MS, 2002 a $2012(\mathrm{em} \%)$

\begin{tabular}{c|c|c|c|c|c|c|c|c|c|c|c}
\hline $\begin{array}{c}\text { Microrregiões/ } \\
\text { Ano }\end{array}$ & 2002 & 2003 & 2004 & 2005 & 2006 & 2007 & 2008 & 2009 & 2010 & 2011 & 2012 \\
\hline $\begin{array}{c}\text { Baixo } \\
\text { Pantanal }\end{array}$ & 6,43 & 6,77 & 6,82 & 7,75 & 8,95 & 8,18 & 9,51 & 8,42 & 8,37 & 8,10 & 7,65 \\
\hline Aquidauana & 2,72 & 2,56 & 2,77 & 2,94 & 2,99 & 2,88 & 2,70 & 2,69 & 2,54 & 2,30 & 2,26 \\
\hline
\end{tabular}

${ }_{17}$ No Brasil, o setor participava com 5,29\% do PIB em 2013. 


\begin{tabular}{c|c|c|c|c|c|c|c|c|c|c|c}
\hline Alto Taquari & 6,32 & 6,31 & 6,08 & 5,67 & 5,31 & 5,41 & 5,29 & 5,44 & 4,89 & 4,62 & 4,78 \\
\hline $\begin{array}{c}\text { Campo } \\
\text { Grande }\end{array}$ & $\begin{array}{c}34,8 \\
7\end{array}$ & $\begin{array}{c}31,9 \\
3\end{array}$ & $\begin{array}{c}33,5 \\
9\end{array}$ & $\begin{array}{c}35,1 \\
9\end{array}$ & $\begin{array}{c}35,3 \\
6\end{array}$ & $\begin{array}{c}34,9 \\
5\end{array}$ & $\begin{array}{c}34,8 \\
2\end{array}$ & $\begin{array}{c}35,1 \\
8\end{array}$ & $\begin{array}{c}34,9 \\
4\end{array}$ & $\begin{array}{c}34,8 \\
2\end{array}$ & $\begin{array}{c}34,3 \\
4\end{array}$ \\
\hline Cassilândia & 4,09 & 4,65 & 4,43 & 3,57 & 3,11 & 3,60 & 3,41 & 3,59 & 3,50 & 3,72 & 3,77 \\
\hline Paranaíba & 2,98 & 2,78 & 3,07 & 3,16 & 3,23 & 3,08 & 3,11 & 3,04 & 3,03 & 2,90 & 2,94 \\
\hline Três Lagoas & 7,10 & 7,20 & 7,99 & 8,14 & 8,17 & 7,54 & 7,62 & 8,52 & 9,27 & 8,84 & 8,65 \\
\hline $\begin{array}{c}\text { Nova } \\
\text { Andradina }\end{array}$ & 3,44 & 3,64 & 4,27 & 4,18 & 4,34 & 3,91 & 3,58 & 3,55 & 3,81 & 3,92 & 3,90 \\
\hline Bodoquena & 3,15 & 3,03 & 3,12 & 3,14 & 3,19 & 3,05 & 3,10 & 3,08 & 2,86 & 2,75 & 2,79 \\
\hline Dourados & 22,2 & 24,2 & 20,5 & 19,6 & 18,8 & 20,7 & 20,2 & 19,7 & 20,0 & 21,3 & 22,2 \\
& 9 & 7 & 7 & 3 & 1 & 9 & 4 & 8 & 5 & 4 & 3 \\
\hline Iguatemi & 6,61 & 6,86 & 7,29 & 6,63 & 6,53 & 6,60 & 6,62 & 6,72 & 6,75 & 6,68 & 6,69 \\
\hline Fonte: IBGE - Contas
\end{tabular}

Fonte: IBGE - Contas Regionais do Brasil

A Tabela 6 apresenta o valor do PIB nominal e o rank de cada microrregião em relação ao produto estadual. Observa-se que Três Lagoas alcançou o terceiro lugar em termos do PIB estadual. Ademais, observa-se uma concentração significativa do produto, uma vez que três microrregiões (Campo Grande, Dourados e Três Lagoas) são responsáveis por mais de 65\% da geração de riqueza de MS (SEMAC, 2012).

Tabela 6- PIB nominal e ranking das microrregiões do estado do Mato Grosso do Sul, 2007 e 2012

\begin{tabular}{c|c|c|c|c}
\hline Microrregiões & $\begin{array}{c}\text { PIB 2007- Valores } \\
\text { Correntes }\end{array}$ & Ranking & $\begin{array}{c}\text { PIB 2012-Valores } \\
\text { Correntes }\end{array}$ & Ranking \\
\hline & $\mathrm{R} \$ 1,00$ & 2007 & $\mathrm{R} \$ 1,00$ & 2012 \\
\hline MRG Alto Taquari & 1.519 .336 .357 & 6 & 2.601 .112 .295 & 6 \\
\hline MRG Aquidauana & 809.621 .969 & 11 & 1.233 .394 .254 & 11 \\
\hline MRG Baixo Pantanal & 2.300 .815 .748 & 3 & 4.166 .680 .692 & 4 \\
\hline MRG Bodoquena & 858.108 .781 & 10 & 1.519 .702 .846 & 9 \\
\hline MRG Campo Grande & 9.840 .245 .418 & 1 & 18.704 .028 .300 & 1 \\
\hline MRG Cassilândia & 1.012 .620 .310 & 8 & 2.052 .176 .116 & 10 \\
\hline MRG Dourados & 5.839 .398 .775 & 2 & 12.111 .244 .242 & 2 \\
\hline MRG Iguatemi & 1.854 .601 .808 & 5 & 3.645 .341 .318 & 5 \\
\hline MRG Nova Andradina & 1.098 .882 .185 & 7 & 2.126 .550 .124 & 7 \\
\hline
\end{tabular}




\begin{tabular}{c|c|c|c|c}
\hline MRG Paranaíba & 867.292 .392 & 9 & 1.600 .200 .112 & 8 \\
\hline MRG Três Lagoas & 2.120 .496 .744 & 4 & 4.711 .017 .039 & 3 \\
\hline
\end{tabular}

Fonte: SEMADE MS (2012)

Do ponto de vista intrarregional, o que se observa é que, dentro da microrregião de interesse, o município de Três Lagoas aumentou a sua já significativa participação (Tabela 7). O município aumentou, também, em termos estaduais, já que sua participação passa de 8,2\% em 2010 para 9,4 em 2013, último ano de referência.

Tabela 7 - Participação municipal no valor adicionado na microrregião de Três Lagoas-MS, 2010 a 2013 (em \%)

\begin{tabular}{c|c|c|c|c}
\hline ANO/MRG & 2010 & 2011 & 2012 & 2013 \\
\hline Água Clara & 6,66 & 5,77 & 6,38 & 5,73 \\
\hline Brasilândia & 6,59 & 11,23 & 8,49 & 5,42 \\
\hline Ribas do Rio Pardo & 7,05 & 7,39 & 8,18 & 7,28 \\
\hline Santa Rita do Pardo & 2,95 & 2,52 & 2,19 & 1,90 \\
\hline Três Lagoas & 76,75 & 73,09 & 74,77 & 79,67 \\
\hline
\end{tabular}

Fonte: IBGE - Contas Regionais do Brasil

Os dados da Tabela 8 mostram a composição setorial do PIB de Três Lagoas ${ }^{18}$. Como observado, a agropecuária é o setor com menor participação relativa no PIB do município e, ademais, tem tendência decrescente, já que, em 1999, representava $11,8 \%$ ante a 3,5\% em 2011. Por outro lado, a indústria tem participação crescente ao longo do período (em 1999 a sua participação era de 21\%; em 2011, 45\%). Ou seja, em linha com as mudanças intersetoriais esperadas para as diferentes etapas do desenvolvimento (Tabela 1), a indústria tem um rápido crescimento em Três Lagoas, o que permite inferir que o município pode ter ingressado na fase da decolagem ${ }^{19}$.

Tabela 8 - Composição setorial do Produto Interno Bruto de Três Lagoas. (em \%)

\begin{tabular}{c|c|c|c}
\hline & Agropecuária & Indústria & Serviços \\
\hline 1999 & 11,8 & 21,4 & 58,5 \\
\hline 2000 & 11,2 & 23,4 & 57,1 \\
\hline 2001 & 11,6 & 29,2 & 50,3 \\
\hline
\end{tabular}

\footnotetext{
${ }^{18} \mathrm{Na}$ comparação com a Tabela 4, é possível identificar a diferenciação da composição do PIB municipal de Três Lagoas com a de MS.

${ }_{19}$ Comparando a Tabela $8 \mathrm{com}$ a Tabela 1, é possível observar que, ao menos, dois critérios que caracterizam a fase da decolagem são bastante evidentes: o declínio do setor primário e o rápido crescimento do setor secundário.
} 


\begin{tabular}{l|l|l|l}
2002 & 11,6 & 27,9 & 50,6 \\
\hline 2003 & 10,0 & 32,7 & 45,2 \\
\hline 2004 & 8,9 & 36,0 & 41,4 \\
\hline 2005 & 8,5 & 30,1 & 48,5 \\
\hline 2006 & 7,4 & 32,6 & 48,0 \\
\hline 2007 & 7,1 & 31,0 & 49,5 \\
\hline 2008 & 7,5 & 32,4 & 46,8 \\
\hline 2009 & 5,9 & 39,3 & 43,4 \\
\hline 2010 & 4,6 & 45,9 & 39,4 \\
\hline 2011 & 3,5 & 44,8 & 40,7 \\
\hline
\end{tabular}

Fonte: Elaborado pelos autores a partir dos dados do IBGE. Valores atualizados pelo IPCA, base 2011 (em mil Reais).

A Figura 3 mostra a taxa de crescimento do PIB industrial e do PIB total para o município de Três Lagoas. Observa-se que o PIB industrial registra taxas reais de crescimento superiores ao PIB total do município na maior parte do período analisado, o que corrobora a importância do setor na economia municipal ${ }^{20}$.

Figura 3 - Taxa de crescimento acumulado do PIB total e industrial de Três Lagoas, 1999-2011 (em taxas reais)

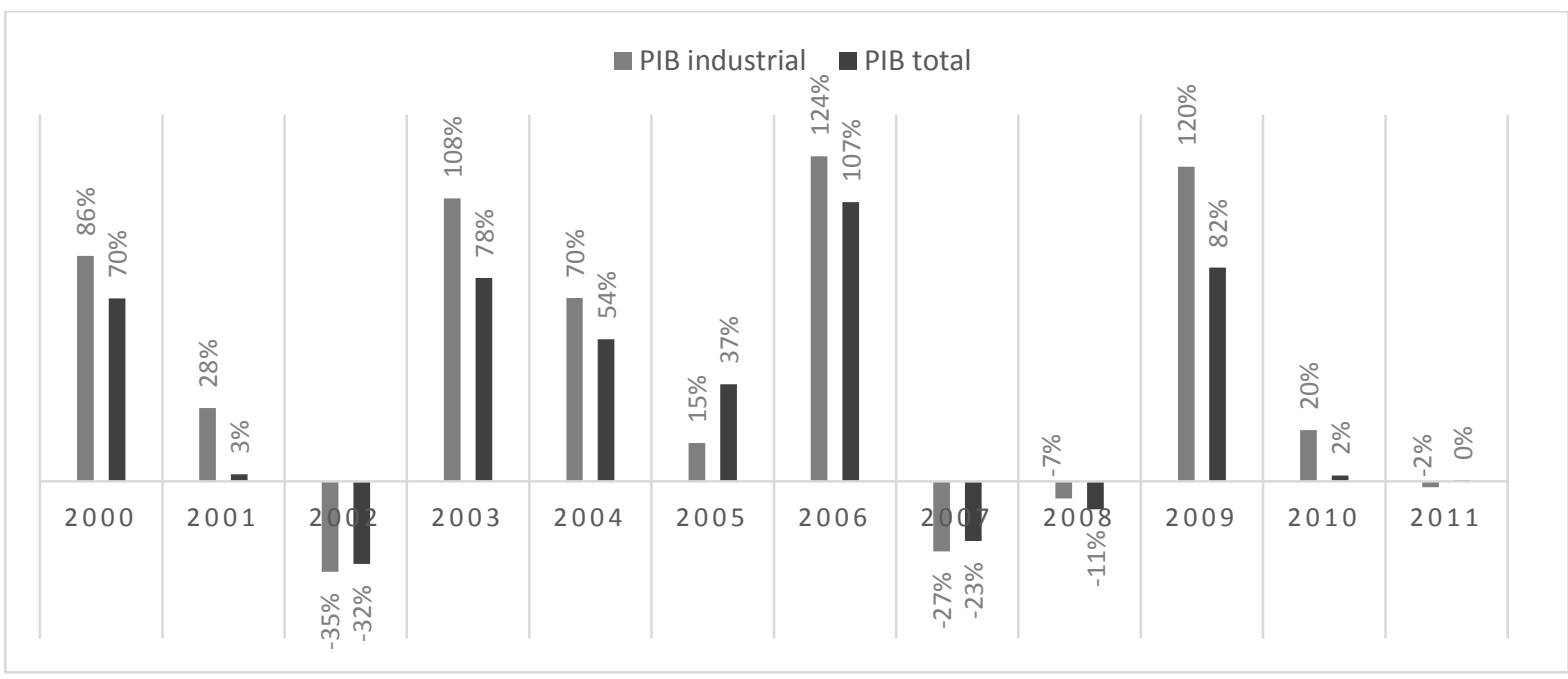

Fonte: Elaborado pelos autores a partir dos dados do IBGE. Valores atualizados pelo IPCA, base 2011 em mil Reais.

${ }^{20}$ Essa é uma tendência que se verifica, também, em termos estaduais. Por exemplo, no período entre 2008-2012, o PIB geral do estado cresceu em média $6 \%$ a.a enquanto o PIB industrial cresceu $9 \%$ (Semac, 2015). 
Enquanto a renda per capita de MS cresceu no período aproximadamente $38 \%$, em Três Lagoas ela cresceu 54\%. Ademais, em 2013, o município registrava a segunda maior renda per capita do Estado.

A Figura 4 demonstra a evolução do emprego por setor na cidade de Três Lagoas. Ressalta-se que o desempenho do setor industrial vem ajudando a impulsionar o crescimento da economia local, ampliando sua capacidade de absorção da força de trabalho. Já a expansão no setor terciário reflete o grau de diversificação e modernização por que vem passando a economia do município (em consonância com a economia estadual), através do avanço quantitativo e qualitativo do setor primário e ampliação de plantas indústrias e agroindustriais, que, no seu conjunto, estão voltadas principalmente para o mercado externo, vêm exigindo cada vez mais a existência de serviços que venham auxiliar no ganho de competitividade dos produtos exportados pelos empresários (SEMAC, 2015). Ademais, a geração de emprego e o aumento da renda têm reflexos na ampliação do consumo interno.

\section{Figura 4 - Evolução do emprego formal da cidade de Três Lagoas, por setor de produção.}

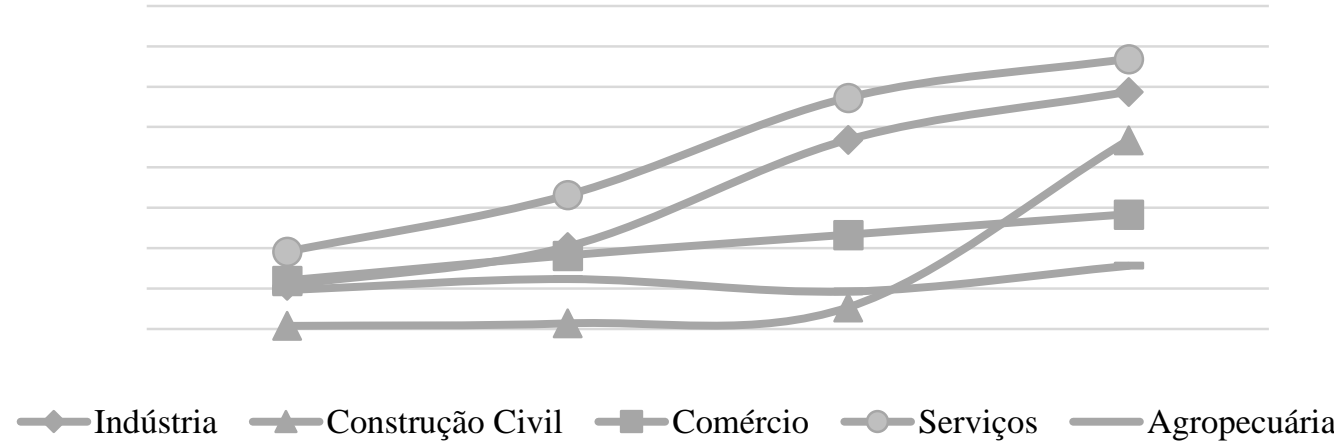

Fonte: Elaborado pelos autores a partir dos dados da RAIS.

O setor que mais empregou foi o de serviços, com uma taxa de crescimento no emprego de $73 \%$ no período 2005/2010, seguido pela indústria, que ultrapassou 1000 admissões em 2013 (no período 2005/2010, o emprego no setor cresceu 130\%). A partir de 2005, ingressaram no município muitas empresas, indústrias do ramo alimentício e de papel e celulose que impulsionaram o emprego em vários setores da 
economia. Esse boom gerou trasbordamentos em quase todos os setores da economia de Três Lagoas.

O setor do comércio apresentou taxa de crescimento do emprego de $52 \%$ do período compreendido entre 2000 a 2005 e, acima de 20\%, nos outros anos. O emprego no setor agropecuário registrou queda de 25\% de 2005 a 2010, em grande parte, como consequência da maior mecanização no campo.

O setor da construção civil destaca-se recentemente com taxa de crescimento de $779 \%$ entre 2010 e 2013. Esse crescimento foi favorecido pelo bom desempenho econômico do município, bem como em consequência dos incentivos do governo federal, especialmente no programa Minha Casa Minha Vida ${ }^{21}$.

A Tabela 9 mostra o número de empresas que estavam em funcionamento nos anos de 2006 a 2013. Os setores com maior quantidade de empresas em funcionamento eram o de comércio, reparação de veículos automotores e motocicletas, seguindo dos setores da indústria de transformação, alojamento e alimentação, serviços e da construção.

Tabela 9 - Os 10 setores com maior número de empresas em Três Lagoas - MS

\begin{tabular}{l|r|r|r|r|r|r|r|r}
\hline Setor & $\mathbf{2 0 0 6}$ & $\mathbf{2 0 0 7}$ & $\mathbf{2 0 0 8}$ & $\mathbf{2 0 0 9}$ & $\mathbf{2 0 1 0}$ & $\mathbf{2 0 1 1}$ & $\mathbf{2 0 1 2}$ & $\mathbf{2 0 1 3}$ \\
\hline Comércio; reparação de veículos automotores e motocicletas & 1076 & 1026 & 1047 & 1092 & 1143 & 1130 & 1138 & 1225 \\
\hline Indústrias de transformação & 237 & 232 & 227 & 248 & 251 & 224 & 234 & 249 \\
\hline Alojamento e alimentação & 121 & 123 & 156 & 168 & 196 & 200 & 218 & 261 \\
\hline Construção & 52 & 52 & 66 & 78 & 90 & 81 & 123 & 142 \\
\hline Outras atividades de serviços & 143 & 131 & 120 & 136 & 162 & 157 & 249 & 219 \\
\hline Transporte, armazenagem e correio & 71 & 75 & 76 & 80 & 98 & 104 & 115 & 129 \\
\hline Atividades profissionais, científicas e técnicas & 60 & 68 & 84 & 103 & 105 & 110 & 115 & 118 \\
\hline Saúde humana e serviços sociais & 47 & 42 & 48 & 65 & 70 & 84 & 94 & 111 \\
\hline Atividades administrativas e serviços complementares & 75 & 79 & 93 & 96 & 122 & 129 & 140 & 173 \\
\hline Agricultura, pecuária, produção florestal, pesca e aquicultura & 41 & 38 & 41 & 44 & 45 & 53 & 51 & 76 \\
\hline
\end{tabular}

Fonte: Elaborado pelos autores a partir dos dados do SIDRA - IBGE - Cadastro Central de Empresas.

Por outro lado, observa-se que, nos setores de agricultura, pecuária, produção florestal, pesca e aquicultura, transporte, armazenagem e correios, atividades administrativas e construção houve um maior número de empresas que iniciaram suas atividades no decorrer do período de 2003 a 2013. Outro setor de destaque nesse sentido é o de saúde humana e serviços sociais, em grande parte como decorrência do incremento no fluxo de pessoas que transitam e/ou residem no município atraídos pelos novos empregos que a região proporciona (Tabela 10). 
Tabela 10- Número de novas empresas por ramo de atividade

\begin{tabular}{c|c|c|c|c|c|c|c}
\hline Setor & 2007 & 2008 & 2009 & 2010 & 2011 & 2012 & 2013 \\
\hline Atividades imobiliárias & 8 & 4 & 7 & 2 & 0 & 3 & 14 \\
\hline Atividades profissionais, científicas e técnicas & 8 & 16 & 19 & 2 & 5 & 5 & 3 \\
\hline Construção & 0 & 14 & 12 & 12 & -9 & 42 & 19 \\
\hline Alojamento e alimentação & 2 & 33 & 12 & 28 & 4 & 18 & 43 \\
\hline $\begin{array}{c}\text { Indústrias de transformação } \\
\text { Atividades administrativas e serviços } \\
\text { complementares }\end{array}$ & -5 & -5 & 21 & 3 & -27 & 10 & 15 \\
\hline $\begin{array}{c}\text { Comércio; reparação de veículos automotores e } \\
\text { motocicletas }\end{array}$ & -50 & 21 & 45 & 51 & -13 & 8 & 87 \\
\hline $\begin{array}{c}\text { Outras atividades de serviços } \\
\text { Transporte, armazenagem e correio }\end{array}$ & -12 & -11 & 16 & 26 & -5 & 92 & -30 \\
\hline Agricultura, pecuária, produção florestal, pesca e \\
aquicultura
\end{tabular}

Fonte: Elaborado pelos autores a partir dos dados do SIDRA - IBGE - Cadastro Central de Empresas.

O crescimento no número de empresas e na oferta de empregos teve um impacto significativo no crescimento populacional de Três Lagoas. Entre 1992 e 1995, a população cresceu 4\%; entre 1995 e 2001, 11\%; e 19\% de 2005 a 2010 (Figura 5), sendo grande parte desse crescimento explicado pelo fluxo migratório de trabalhadores para a região. Figura 5 - Evolução do crescimento populacional e a variação de crescimento
populacional no município de Três Lagoas.

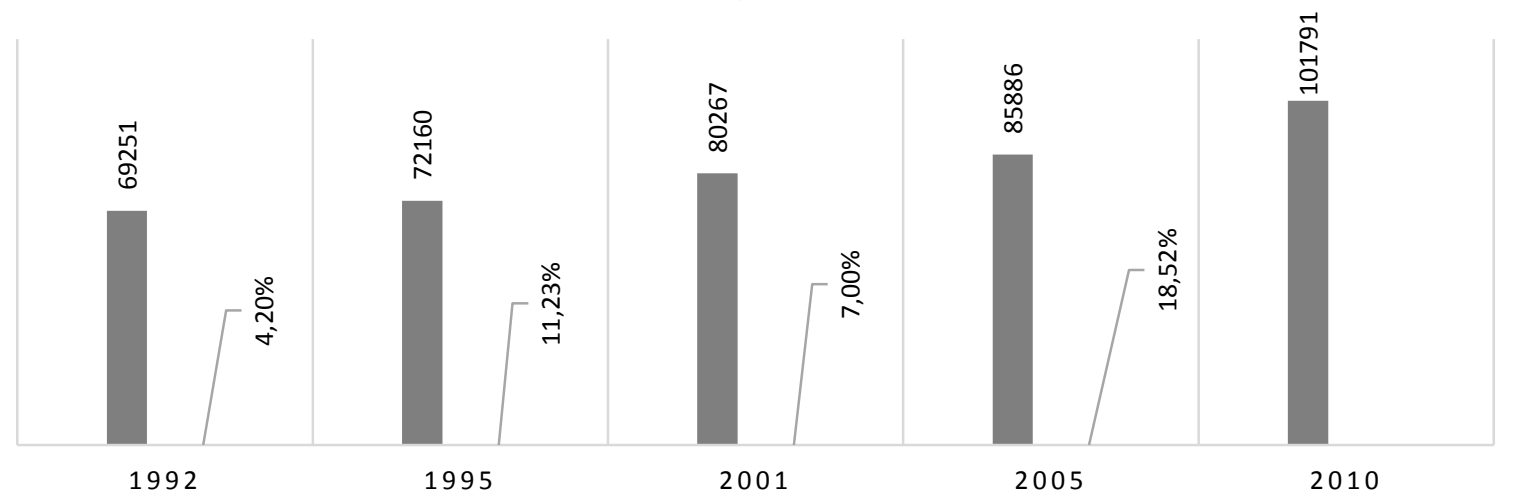

Fonte: Elaborado pelos autores a partir dos dados do IBGE 
A análise do comércio internacional do município de Três Lagoas demonstra que as exportações cresceram significativamente a partir de 2009, com destaque para o período 2013-2015. Esse crescimento permitiu reverter o saldo negativo da balança comercial, que predominou ao longo do período em grande parte dada a necessidade de importação de máquinas e equipamentos para a instalação das indústrias de celulose. Após o início das operações dessas empresas, as exportações se elevaram.

Tabela 11 - Balança comercial de Três Lagoas, 2000-2015.

\begin{tabular}{c|c|c|c|c|c}
\hline \multirow{2}{*}{ Ano/Mês } & \multicolumn{2}{|c|}{ Exportação } & \multicolumn{2}{c}{ Importação } & Saldo \\
\cline { 2 - 6 } & US\$ FOB (A) & Var\% & US\$ FOB (B) & Var\% & US \$ FOB (A) - (B) \\
\hline 2000 & $29,299,650$ & 0.00 & $10,747,502$ & 0.00 & $18,552,148$ \\
\hline 2001 & $36,651,451$ & 25.09 & $16,191,211$ & 50.65 & $20,460,240$ \\
\hline 2002 & $14,011,205$ & -61.77 & $17,171,946$ & 6.06 & $-3,160,741$ \\
\hline 2003 & $7,615,185$ & -45.65 & $40,029,593$ & 133.11 & $-32,414,408$ \\
\hline 2004 & $50,196,388$ & 559.16 & $80,386,807$ & 100.82 & $-30,190,419$ \\
\hline 2005 & $71,166,841$ & 41.78 & $135,773,218$ & 68.90 & $-64,606,377$ \\
\hline 2006 & $12,518,611$ & -82.41 & $251,322,286$ & 85.10 & $-238,803,675$ \\
\hline 2007 & $9,168,478$ & -26.76 & $312,349,978$ & 24.28 & $-303,181,500$ \\
\hline 2008 & $15,729,254$ & 71.56 & $438,289,540$ & 40.32 & $-422,560,286$ \\
\hline 2009 & $347,032,960$ & 2106.29 & $644,909,438$ & 47.14 & $-297,876,478$ \\
\hline 2010 & $665,008,891$ & 91.63 & $545,448,672$ & -15.42 & $119,560,219$ \\
\hline 2011 & $649,757,469$ & -2.29 & $714,352,929$ & 30.97 & $-64,595,460$ \\
\hline 2012 & $645,128,151$ & -0.71 & $835,835,403$ & 17.01 & $-190,707,252$ \\
\hline 2013 & $1,158,823,675$ & 79.63 & $973,977,848$ & 16.53 & $184,845,827$ \\
\hline 2014 & $1,153,610,449$ & -0.45 & $619,657,287$ & -36.38 & $533,953,162$ \\
\hline 2015 & $1,131,570,212$ & -1.91 & $357,282,895$ & -42.34 & $774,287,317$ \\
\hline
\end{tabular}

Fonte: MDIC, 2016.

Os dados acima evidenciam os resultados econômicos da decolagem no município de Três Lagoas. Não obstante, o desenvolvimento não se restringe somente a essa dimensão. A elevação da renda e do emprego no município promovida pelo processo de industrialização atrai trabalhadores, por exemplo, o que impacta sobre os serviços de saúde, saneamento básico, educação, segurança, entre outros. 
No município, o crescimento relacionado às despesas com saúde e saneamento básico teve uma variação percentual de $644 \%$, em valores nominais, na comparação dos anos 2000 com 2010 (Zucchi, Nero e Malik, 2000). O aumento dessas despesas é consequência do crescimento acelerado, especialmente do seu núcleo urbano.

A seguir, apresenta-se um conjunto de indicadores que buscam mensurar 0 desenvolvimento econômico do município sob diferentes aspectos. O Índice de Desenvolvimento Humano Municipal (IDHM) é uma medida composta de indicadores de três dimensões do desenvolvimento humano: longevidade, educação e renda. $O$ índice varia de 0 a 1 . Quanto mais próximo de 1, maior o desenvolvimento humano. Os dados mostram que Três Lagoas tem avançado nas três dimensões, melhorando inclusive sua posição relativa dentre os demais municípios brasileiros.

Tabela 11 - Índice de Desenvolvimento Humano Municipal (IDHM) de Três Lagoas (MS)

\begin{tabular}{c|c|c|c|c|c}
\hline Ano & $\begin{array}{c}\text { Ranking IDHM } \\
\text { nacional }\end{array}$ & IDHM & IDHM Renda & IDHM Longevidade & $\begin{array}{c}\text { IDHM } \\
\text { Educação }\end{array}$ \\
\hline 1991 & $710^{\circ}$ & 0,505 & 0,633 & 0,670 & 0,303 \\
\hline 2000 & $985^{\circ}$ & 0,630 & 0,687 & 0,763 & 0,477 \\
\hline 2010 & $667^{\circ}$ & 0,744 & 0,752 & 0,849 & 0,645 \\
\hline
\end{tabular}

Fonte: Atlas do Desenvolvimento Humano no Brasil 2013 (Com dados dos Censos 1991, 2000 e 2010.)

O Índice FIRJAN de Desenvolvimento Municipal (IFDM) ${ }^{22}$ acompanha o desenvolvimento socioeconômico dos municípios brasileiros com base nas três áreas fundamentais ao desenvolvimento humano: educação, saúde e emprego e renda. A Tabela 12 mostra os dados para Três Lagoas, o que permite classificar o desenvolvimento do município como alto.

Tabela 12 - Índice FIRJAN de desenvolvimento municipal para Três Lagoas - ano base 2013.

\begin{tabular}{c|c|c|c|c|c}
\hline \multicolumn{2}{c|}{ Ranking IFDM Geral } & \multirow{2}{*}{ IFDM } & $\begin{array}{c}\text { Emprego e } \\
\text { Renda }\end{array}$ & Educação & Saúde \\
\cline { 1 - 2 } Nacional & Estadual & 0,8494 & 0,8955 & 0,7528 & 0,8998 \\
\hline $96^{\circ}$ & $2^{\circ}$ & 0,898 &
\end{tabular}

Fonte: Firjan, 2013.

${ }^{22}$ Criado pela Federação das Indústrias do Estado do Rio de Janeiro (FIRJAN). O índice varia de 0 (mínimo) a 1 ponto (máximo) para classificar o nível de cada cidade em quatro categorias: baixo (de 0 a 0,4$)$, regular $(0,4001$ a 0,6$)$, moderado (de 0,6001 a 0,8$)$ e alto desenvolvimento $(0,8001$ a 1$)$. 
O Índice FIRJAN de Gestão Fiscal (IFGF) é um estudo anual construído com base em estatísticas oficiais, a partir de dados declarados pelos municípios à Secretaria do Tesouro Nacional (STN). A pontuação que os municípios recebem depende da avaliação de cinco tipos de indicadores: receita própria, gastos com pessoal, investimentos, liquidez e custo da dívida. ${ }^{23} \mathrm{~A}$ Tabela 13 apresenta os dados do IFGF para Três Lagoas, destacando a sua posição no cenário estadual (ocupando a primeira posição) e permitindo classificar a gestão municipal, segundo critérios do índice, como boa.

Tabela 13 - Índice FIRJAN de gestão fiscal para Três Lagoas- ano base 2013.

\begin{tabular}{c|c|c|c|c|c|c|c}
\hline \multicolumn{2}{c|}{ Ranking IFGF Geral } & \multirow{2}{*}{ IFGF } & $\begin{array}{c}\text { Receita } \\
\text { Própria }\end{array}$ & $\begin{array}{c}\text { Gastos } \\
\text { com } \\
\text { Pessoal }\end{array}$ & Investimentos & Liquidez & $\begin{array}{c}\text { Custo da } \\
\text { Dívida }\end{array}$ \\
\hline $118^{\circ}$ & $1^{\circ}$ & 0,7217 & 0,6370 & 0,7013 & 0,8311 & 0,6660 & 0,8369 \\
\hline
\end{tabular}

Fonte: Firjan, 2013.

Os dados apontados acima sugerem que o município de Três Lagoas se encontra no início do processo de decolagem, especialmente porque apresenta crescimento significativo do setor industrial.

\section{Considerações Finais}

Realizou-se um exercício teórico/analítico a fim de caracterizar as fases de desenvolvimento do município de Três Lagoas-MS e, assim, averiguar se ele já estabeleceu as pré-condições necessárias para o chamado "arranco" econômico. Com base na análise de indicadores, sugere-se uma resposta afirmativa, ou seja, existem evidências de que o município se encontra na fase inicial do processo de decolagem (forte expansão do setor industrial e participação decrescente da agropecuária no valor adicionado municipal).

Nesse contexto, constatou-se que o município empreendeu uma sequência de ações para dar suporte ao arranco, com destaque aos projetos de infraestrutura de transporte e energia e a ação governamental. Ou seja, destacam-se dois importantes instrumentos complementares de atração: o da logística e o das políticas fiscais. Além disso, o município tem se beneficiado de sua posição estratégica, já que se encontra

${ }^{23}$ Ela varia de 0 a 1 , sendo que, quanto maior a pontuação, melhor a gestão fiscal do município. $E$ os conceitos vão de $A$ a $D$, da seguinte forma: $A$ - gestão de excelência (acima de 0,8001 ); $B$ - boa gestão (entre 0,6001 e 0,8); C - gestão em dificuldade (entre 0,4001 e 0,6); e, D - gestão crítica (inferior a 0,4). 
situado na fronteira com o estado de São Paulo, importante centro consumidor e distribuidor para outras regiões.

Em síntese, observa-se que, nesse processo recente, iniciou-se uma trajetória construtiva que envolve a "materialização ideológica de uma teoria de localização atraente, alicerçada na complexidade logística regional e no empenho político institucional dos governos estadual e municipal (JURADO, 2008, p. 152)", seguido de um processo onde a execução dos empreendimentos (pelo menos inicialmente) se materializaram na instalação de grandes e médias indústrias (empresas).

Assim, é possível evidenciar que estratégias adotadas até o presente momento permitiram taxas de crescimento expressivas e o aumento da renda per capita no município. Contudo, ao avançar esse estágio, a manutenção dessas taxas será condicionada à mudança das estratégias de crescimento, no sentido de elevar a produtividade e incorporar a produção de bens inovadores no intuito de garantir a inserção em cadeias globais de valor e a continuidade do processo de desenvolvimento. Ou seja, as mudanças ocorridas são pré-requisitos necessários, mas não suficientes para garantir a continuidade do processo de decolagem.

Isso porque, à mercê do desempenho positivo alcançado nos últimos anos, é necessário aprofundar o processo de transformação estrutural para evitar que os ganhos iniciais se esgotem. Para tanto, além do que anteriormente mencionado, é preciso avançar na construção real de vantagens competitivas adquiridas, como a contínua melhoria das questões logísticas, por exemplo. Ou seja, apesar da infraestrutura existente, sabe-se que existe uma série de limitações que cercam cada uma das modalidades de escoamento caracterizado em Três Lagoas. Do ponto de vista da ferrovia Noroeste do Brasil (hoje Novoeste), sabe-se que a situação atual é de falta de investimentos e de certo sucateamento estrutural. Assim, a retomada qualitativa dos serviços da ferrovia está condicionada à realização de consideráveis investimentos de capital na recuperação e manutenção da malha. Em relação ao transporte hidroviário, deve-se destacar que a opção pela hidrovia Tietê-Paraná tem sido pouco utilizada, em grande parte, pela ausência de infraestrutura portuária em boa parte do prolongamento da hidrovia. Por outro lado, é necessário considerar que a energia hidroelétrica produzida em Jupiá, bem como a de todo o complexo gerador 
Tietê-Paraná, é descarregada em linhões de transmissão do Sistema Nacional e que a vantagem competitiva proveniente do "gás boliviano" tende a ser ligeiramente desqualificada dada a instabilidade dos contratos de comercialização do gás, firmados entre o Brasil e a Bolívia, e nos custos de implantação ou conversão tecnológica necessários para o seu aproveitamento energético, como destaca Jurado (2008).

Ressalta-se, também, a necessidade de se avançar em questões sociais importantes. O desenvolvimento recente do município trouxe consigo o crescimento populacional e a amplificação das contradições referente à organização social e até mesmo urbana. São exemplos provenientes da atração e da ocupação não coordenada de um contingente de trabalhadores semiespecializados os problemas relativos a moradia, educação, saúde e segurança, entre outras, associados muitas vezes ao atraso no marco regulatório do poder público municipal.

Por fim, é preciso avançar em dois pontos fundamentais: educação e inovação tecnológica. Como os dados analisados mostram, a educação é o índice com pior desempenho no município e constitui-se em desafio a ser superado no curto/médio prazo. Por outro lado, a baixa intensidade tecnológica da produção municipal gera problemas de especialização e de baixa complexidade econômica, o que implica na exportação de produtos primários ou semi-industrializados. A exportação desses produtos associados à concentração do mercado exportador a um (China) ou a um pequeno grupo de países pode ocasionar ciclos de crescimento/recessão deslocados da realidade local. Nesse contexto, a desaceleração do crescimento chinês é um desafio para os próximos anos. Ademais, boa parte das empresas instaladas no município são filiais e, portanto, atendem a uma lógica externa, o que pode acabar limitando os projetos de reinvestimentos e de expansão de suas atividades no município.

\section{REFERÊNCIAS}

ARORA, R. U. 2009. Globalization and stages of development: An exploratory analysis. Review of Urban and Regional Development Studies, 212-3, 124-142. doi:10.1111/j.1467940X.2010.00164.x

BULHÕES, O. D. de. Algumas considerações sobre as fases do desenvolvimento econômico, Revista Brasileira de Economia, v. 14, n.3, p. 5-15, 1960. 
CAIRNCROSS, A. K. The Stages of Economic Growth. The Economic History Review, New Series, v. 13, n. 3, p. 450-458, 1961.

CAMPOS, R. A Lanterna na Popa: memórias. Rio de Janeiro, Topbooks, vol. 1, 1994.

CÂNDIDO. A. Teorias do desenvolvimento e desenvolvimento no Brasil. Mossoró: UERN, 1999.

DUTRA, J. A. A. Tecnologia da Informação e Desenvolvimento Agrícola Regional: estudo de caso no município de Balsas - MA. Dissertação (Mestrado) Programa de Pós-Graduação em Desenvolvimento Regional - Universidade de Santa Cruz do Sul - UNISC, 2012, 102 f..

EBERHARDT, P. H. de C. Estágios de desenvolvimento econômico regional no Sul do Brasil. Dissertação (Mestrado) em Desenvolvimento Regional e Agronegócio - Universidade Estadual do Oeste do Paraná. Toledo, PR: [s. n.], 2013, $102 f$.

FIRJAN. Disponível em: <http://www.firjan.com.br/ifdm/>

FRANCISCO, A. L. Ciclos Econômicos Aportados Na Cidade De Três Lagoas - Da Pecuária As Indústrias De Transformação. Tese de mestrado pela UFMS, 2013.

HOSELITZ, B. F. Theories of stages of economic growth. In: Hozelitz BF. (ed.), Theories of Economic Growth. Glencoe, II: Free Press., 1960.

ITAGAKI, Y. Criticism of Rostow's Stage Approach: the concepts of state, System and Type. Developing Economies, v. 1, n. 1, p. 8-17, 1963.

JURADO, F. L. S. O Processo de Industrialização na Cidade de Três Lagoas (MS): Discursos, desdobramentos e contradições. Dissertação apresentada no Programa de Mestrado em Geografia da Universidade Federal de Mato Grosso do Sul, 207 p., 2008.

KUZNETS, S. Notes on the take-off. In: Rostow WW. (ed.), The Economics of Take-Off into Sustained Growth. London: Macmillan, 1963.

NORTH, D. Location theory and regional economic growth. Journal of Political Economy, vol. 63, p. 243-158, 1955.

OLIVEIRA, P. De. As Relações Entre As Indústrias De Três Lagoas-Ms No Contexto De Territorialidade: Um Estudo Com Perspectivas De Desenvolvimento Local. Campo Grande, UCDB, Tese- (Mestrado Em Desenvolvimento Local), 2006.

OLIEIRA, N. M de; EBERHARDT, P. H. De C.; LIMA, J. F. Notas sobre as etapas de desenvolvimento econômico: uma análise para a região sul. VI Seminário Internacional sobre Desenvolvimento Regional, Santa Cruz do Sul, RS, Brasil, setembro de 2013.

PARR, J. B. On the regional dimensions of Rostow's theory of Growth. Review of Urban and Regional Development Studies, v. 13, n.1, p. 2-19, 2001.

PAVÃO, E. S. Formação, Estrutura E Dinâmica Da Economia De Mato Grosso Do Sul No Contexto Das Transformações Da Economia Brasileira. Florianópolis. UFSC, Dissertação: (Mestre em Economia Industrial), 2005. 
PELINSKI, A. Padrão de desenvolvimento econômico dos municípios do Paraná:

Disparidade, dispersão, e fatores exógenos. Dissertação de Mestrado (Programa de PósGraduação em Desenvolvimento Regional e Agronegócio - Mestrado) - Universidade Estadual do Oeste do Paraná - Unioeste. Toledo. 2007.

PEREIRA, R.C. O.; GOMES, C. A. Q. O Recente Processo De Industrialização De Três Lagoas-MS. Economia \& Pesquisa, Araçatuba, v.6, n.6, p. 50-65, 2004.

PERROUX, F. Nota sobre a noção de pólo de crescimento, in: SCHWARTZMAN, Jacques. Economia Regional: textos escolhidos. Belo Horizonte: CEDEPLAR. 1977, p. 145-55.

PIACENTI, C. A. O potencial de desenvolvimento endógeno dos municípios paranaenses. Tese de Doutorado (Programa de Pós-Graduação em Economia Aplicada -Doutorado) Universidade Federal de Viçosa. UFV. 2009.

POTTER, R.B.; BINNS, T.; ELLIOTT, J.; SMITH, D. Geographies of Developmnent. London: Longman, 1999.

PPA-Dimensão Estratégica <http://www.planejamento.gov.br/secretarias/upload /Arquivos/spi/PPA/2012/mp_002_Dimensao_Estrategica.pdf> acesso em 11/03/2015.

PREFEITURA DE TRÊS LAGOAS: <http://www.treslagoas.ms.gov.br/view/a-cidade/nossahistoria/1/>acesso em 07/11/2014.

RAIS <http://bi.mte.gov.br/bgcaged/caged_rais_vinculo_id_2001/login.php > acesso em 13/03/2015.

ROSTOW, W. W. The take-off into self-sustained growth. The Economic Journal, v. 66, n. 261, p. 25-48, 1956.

\section{9.}

The stages of economic growth. Economic History Review, v. 12, n. 1, p. 1-16,

Etapas do desenvolvimento econômico (um manifesto não comunista). 6. ed. ampl. Rio de Janeiro: Zahar, 1978.

A decolagem para o crescimento autossustentado. In: AGARWALA, A. N.; SINGH, S. P. (Org.). A economia do subdesenvolvimento. Rio de Janeiro: Contraponto; Centro Internacional Celso Furtado, 2010.

SARMENTO, A. D. Etapas Do Desenvolvimento Econômico No Brasil - Um Exercício Rostowiano. São Paulo 2008, tese USP.

XAVIER, C. H. C.; SANTOS, C. R. dos; ALCALDE, E de A.; SOUZA, M. L. L. de. O Início Do Processo De Industrialização Em Três Lagoas/MS: Uma Análise Das Primeiras Indústrias. Revista Conexão Eletrônica, v. 9, n. 1/2- ano 2012. p. 348-363.

ZUCCHI, P.; NERO, C. Del; MALIK, A. M. Gastos Em Saúde: Os Fatores Que Agem Na Demanda E Na Oferta Dos Serviços De Saúde. Saúde e Sociologia, v. 9, n. 1, p. 127-150, 2000. 


\section{NOTAS DE AUTOR}

\section{CONTRIBUIÇÃO DE AUTORIA}

Fabricio José Missio - Concepção. Análise de dados, Elaboração do manuscrito, revisão e aprovação da versão final do trabalho

Claudia Maria Sonaglio - Participação ativa da discussão dos resultados; Revisão da versão final do trabalho. Bruna Maria Oliveira Benites Ferreira - Elaboração do manuscrito. Coleta e análise dos dados.

\section{FINANCIAMENTO}

Fabricio José Missio - o autor gostaria de agradecer à Capes e ao Cnpq pela bolsa de produtividade em pesquisa.

Bruna Maria Oliveira Benites Ferreira - a autora gostaria de agradecer a Fundação de Apoio ao Desenvolvimento do Ensino, Ciência e Tecnologia do Estado de Mato Grosso do Sul (Fundect) pela bolsa de mestrado.

\section{CONSENTIMENTO DE USO DE IMAGEM}

Não se aplica.

APROVAÇÃO DE COMITÊ DE ÉTICA EM PESQUISA

Não se aplica.

\section{CONFLITO DE INTERESSES}

Não se aplica.

\section{LICENÇA DE USO}

Este artigo está licenciado sob a Licença Creative Commons CC-BY. Com essa licença você pode compartilhar, adaptar, criar para qualquer fim, desde que atribua a autoria da obra.

\section{HISTÓRICO}

Recebido em: 30-09-2017

Aprovado em: 08-09-2018 